\title{
Fe(IV) Alkylidenes Are Actually Fe(II), and a Related Octahedral Fe(II) "Alkylidene" Is a Conjugated Vinyl Complex
}

\author{
Brian P. Jacobs, ${ }^{a}$ Rishi G. Agarwal, ${ }^{a}$ Peter T. Wolczanski ${ }^{*},{ }^{a}$ Thomas R. Cundari ${ }^{*},{ }^{b}$ and Samantha N. \\ MacMillan $^{a}$ \\ ${ }^{a}$ Department of Chemistry \& Chemical Biology, Baker Laboratory, Cornell University, Ithaca, New York \\ 14853 (USA); E-mail: ptw2@cornell.edu \\ ${ }^{b}$ Department of Chemistry, Center for Advanced Scientific Computing and Modeling (CASCaM), \\ University of North Texas, Box 305070, Denton, Texas 76203-5070; E-mail: Thomas.Cundari@unt.edu \\ ${ }^{\ddagger}$ Dedicated to Prof. Malcolm L. H. Green, candidate for the Mt. Rushmore of organometallic chemistry, \\ on the occasion of his 80th birthday; we greatly appreciate his contributions and enthusiasm.
}

keywords: iron, alkylidene, vinyl, azaallyl, calculation

(C) 2016. This manuscript version is made available under the Elsevier user license http://www.elsevier.com/open-access/userlicense/1.0/ 


\begin{abstract}
:
Electronic structure calculations on previously synthesized [mer- $\left\{\mathrm{K}-\mathrm{C}, \mathrm{N}, \mathrm{C}-\left(2-\mathrm{C}_{6} \mathrm{H}_{4}\right) \mathrm{CH}=\mathrm{N}(1,2-\right.$ $\left.\left.\left.\mathrm{C}_{6} \mathrm{H}_{4}\right) \mathrm{C}\left({ }^{\mathrm{i}} \mathrm{Pr}\right)=\right\} \mathrm{Fe}\left(\mathrm{PMe}_{3}\right)_{3}\right]\left[\mathrm{BAr}_{4}^{\mathrm{F}}\right]$ (1) and mer, trans- $\left.\left\{\kappa-\mathrm{C}, \mathrm{N}, \mathrm{C}-\left(2-\mathrm{C}_{6} \mathrm{H}_{4}\right) \mathrm{CH}(\mathrm{Bn}) \mathrm{N}\left(1,2-\mathrm{C}_{6} \mathrm{H}_{4}\right) \mathrm{C}\left({ }^{\mathrm{i}} \mathrm{Pr}\right)=\right\} \mathrm{Fe}(\mathrm{PMe})_{3}\right)_{2} \mathrm{~N}_{2}$ (4-Bn) reveal that 1 is best interpreted as Fe(II) bound to a carbenium ion, while 4-Bn has an iminovinyl unit bound to a ferrous center. Attempts to prepare $L_{n} F e=C H R$ species capable of olefin metathesis or carbene transfer were obviated by alternative reactivity, although precursors mer, trans$\left\{\kappa^{3}-\mathrm{N}, \mathrm{N}, \mathrm{C}-(2-\mathrm{py}) \mathrm{CH}=\mathrm{NCH}_{2} \mathrm{CH}=\mathrm{CH}\right\} \mathrm{Fe}\left(\mathrm{PMe}_{3}\right)_{2} \mathrm{CH}_{3} \quad$ (6), [mer, trans $-\left\{\kappa^{3}-\mathrm{N}, \mathrm{N}, \mathrm{C}-2-\mathrm{py}-\right.$ $\left.\left.\mathrm{CH}=\mathrm{NCH}_{2} \mathrm{CH}=\mathrm{CH}\right\} \mathrm{Fe}\left(\mathrm{PMe}_{3}\right)_{2} \mathrm{CH}_{3}\right] \quad\left[\mathrm{PF}_{6}^{-}\right] \quad\left(8^{+}\right)$, mer, trans $-\left\{\kappa^{3}-\mathrm{N}, \mathrm{N}, \mathrm{C}-2-\mathrm{py}-\mathrm{CH}=\mathrm{NCH}_{2} \mathrm{CH}=\mathrm{CH}\right\} \mathrm{Fe}\left(\mathrm{PMe}_{3}\right)_{2} \mathrm{I}$ (9), $\operatorname{mer}-\left\{\kappa^{3}-\mathrm{N}, \mathrm{N}, \mathrm{C}-(2-\right.$ pyridyl $\left.) \quad \mathrm{CHNCHCHCH}\right\} \mathrm{Fe}\left(\mathrm{PMe}_{3}\right)_{3} \quad(11), \quad$ and $\quad m e r-\left\{\kappa^{3}-\mathrm{C}, \mathrm{N}, \mathrm{C}-(2-\right.$ $\left.\left.\mathrm{C}_{6} \mathrm{H}_{4}\right) \mathrm{CH}=\mathrm{NCH}_{2} \mathrm{CH}=\mathrm{CH}\right\} \mathrm{Fe}\left(\mathrm{PMe}_{3}\right)_{3}(12)$ were prepared. Related phenyl derivatives, mer, trans $-\left\{\kappa^{3}-\mathrm{N}, \mathrm{N}, \mathrm{C}-\right.$ (2-py) $\left.\mathrm{CH}=\mathrm{NC}(\mathrm{Me})_{2} \mathrm{CH}=\mathrm{CH}\right\} \quad \mathrm{Fe}\left(\mathrm{PMe}_{3}\right)_{2} \mathrm{CH}_{3} \quad$ (13) and $\quad$ mer, trans $-\left\{\mathrm{K}^{3}-\mathrm{N}, \mathrm{N}, \mathrm{C}-(2-\right.$ py) $\left.\left.\mathrm{CH}=\mathrm{NC}(\mathrm{Me})_{2} \mathrm{CH}=\mathrm{CH}\right\} \mathrm{Fe}\left(\mathrm{PMe}_{3}\right)_{2} \mathrm{~N}_{2}\right]\left[\mathrm{BAr}_{4}^{\mathrm{F}}\right]$ (15) were prepared to test additional stability issues. Compounds 9 and 11 were structurally characterized, and metrical parameters of the latter, in addition to electronic structure calculations, suggest that it is not an alkylidene, but an Fe(II) center coordinated by a conjugated vinyl ligand with extensive delocalization in its $\pi$-system.
\end{abstract}




\section{Introduction}

Iron alkylidene complexes capable of catalyzing olefin metathesis [1-3] are intriguing synthetic targets in organometallic chemistry. While ruthenium [4] and molybdenum [5] catalysts are currently employed in a variety of applications, the generation of an effective base-metal system has the potential to elicit more applications in commodity chemicals, where cost is of paramount importance. Calculations indicate that catalysts must be $d^{n}(n \leq 4)$ in order to enable the necessary olefin/alkylidene to metalacyclobutane conversion crucial to metathesis, [6] hence Fe(IV) alkylidene complexes are plausible solutions.

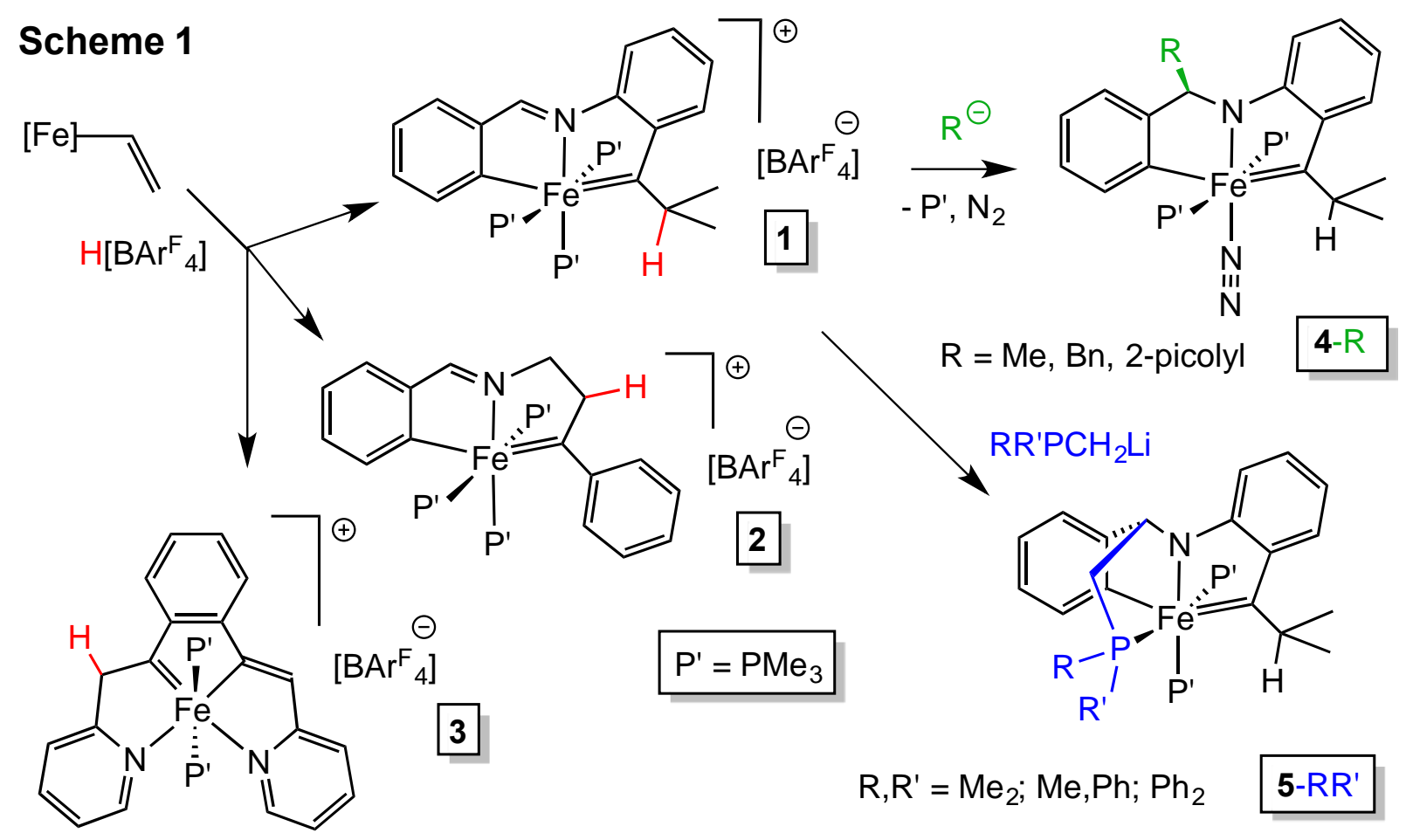

In the course of investigating $\mathrm{Fe}(\mathrm{IV})$ alkylidenes in these laboratories, [7,8] the number of structurally characterized species was increased substantially, but the new compounds failed to exhibit the desired reactivity. As illustrated in Scheme 1, protonation [9-13] of iron-vinyl complexes afforded cationic alkylidenes 1, 2, and 3, but even under circumstances in which $\mathrm{PMe}_{3}$ loss was noted, no olefin 
metathesis or cyclopropanation was observed.[7] In first row transition metal cationic complexes, the $3 \mathrm{~d}$ orbitals can be contracted to the extent that metal-ligand multiple bonding is diminished. As a consequence, neutral iron alkylidenes were produced via nucleophilic attack at the imines of cation 1 (4-R), including several with a pendant side-arm (5-R,R').[8] No consequential reactivity was observed for these derivatives, again despite evidence of phosphine dissociation, which is likely to be necessary prior to alkylidene reactivity.

One obvious disparity between complexes that enable olefin metathesis, and those in Scheme 1 , are the substituents on the alkylidenes. Virtually every metal-carbon double bond that reacts with an olefin is of the type $M=C(H) R .[14]$ In this manuscript, attempts at generating iron alkylidenes with hydrogen substituents are described, and two of the alkylidenes in Scheme 1, cation [mer-\{K-C,N,C-(2$\left.\left.\left.\mathrm{C}_{6} \mathrm{H}_{4}\right) \mathrm{CH}=\mathrm{N}\left(1,2-\mathrm{C}_{6} \mathrm{H}_{4}\right) \mathrm{C}\left({ }^{\mathrm{P} P r}\right)=\right\} \mathrm{Fe}\left(\mathrm{PMe}_{3}\right)_{3}\right]\left[\mathrm{BAr}_{4}^{\mathrm{F}}\right]\left(1, \mathrm{BAr}_{4}{ }_{-}^{-}=\left[\mathrm{B}\left(3,5-\left(\mathrm{CF}_{3}\right)_{2}-\mathrm{C}_{6} \mathrm{H}_{3}\right)_{4}\right]^{-}\right),[7]$ and neutral mer- $\{\kappa-$ $\mathrm{C}, \mathrm{N}, \mathrm{C}-\left(2-\mathrm{C}_{6} \mathrm{H}_{4}\right) \mathrm{CH}(\mathrm{Bn}) \mathrm{N}\left(1,2-\mathrm{C}_{6} \mathrm{H}_{4}\right) \mathrm{C}\left({ }^{\prime} \mathrm{Pr}\right)=3 \mathrm{Fe}\left(\mathrm{PMe}_{3}\right)_{3} \quad(4-\mathrm{Bn})$ [8] are evaluated via computation. In addition, an unusual dianionic chelate was found to distribute charge rather than form an $\mathrm{Fe}(\mathrm{II})$ alkylidene, as a testament to Hoffmann's calculations, [6] and the ability of pyridine-imine/azaallyl species to stabilize charge.[15-18]

\section{Results and Discussion}

\subsection{Calculations of "Fe(IV)" Alkylidenes.}

2.1.1. Calculation of $\left[m e r-\left\{\kappa-C, N, C-\left(2-C_{6} H_{4}\right) C H=N\left(1,2-C_{6} H_{4}\right) C\left({ }^{i} \mathrm{Pr}\right)=\right\} F e\left(P M e_{3}\right)_{3}\right]\left[B A r_{4}^{F}\right](1)$.

Fig. 1 illustrates a truncated molecular orbital diagram of $\left[\right.$ mer- $\left\{\kappa-C, N, C-\left(2-\mathrm{C}_{6} \mathrm{H}_{4}\right) \mathrm{CH}=\mathrm{N}(1,2-\right.$ $\left.\left.\mathrm{C}_{6} \mathrm{H}_{4}\right) \mathrm{C}\left({ }^{\mathrm{i}} \mathrm{Pr}\right)=3 \mathrm{Fe}\left(\mathrm{PMe}_{3}\right)_{3}\right]\left[\mathrm{BAr}_{4}^{\mathrm{F}}\right]$ (1), [7] which includes the portrayal of a select number of crucial orbitals. Metrics of the calculated cation are within $0.03 \AA \AA$ of the X-ray crystal structure determination, and the 

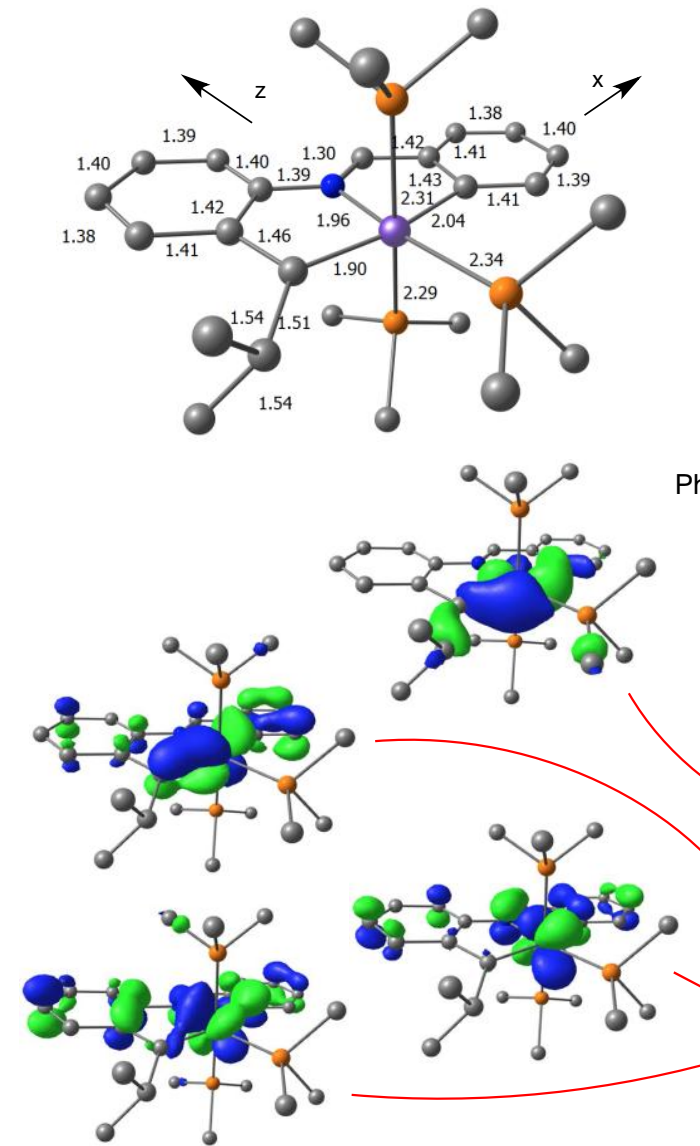

$/ \mathrm{N} / \mathrm{C}(\mathrm{p})^{*}+(\mathrm{py}(\mathrm{p}))$

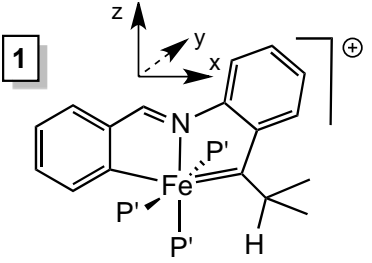

$\mathrm{FeL} *$

$$
P^{\prime}
$$

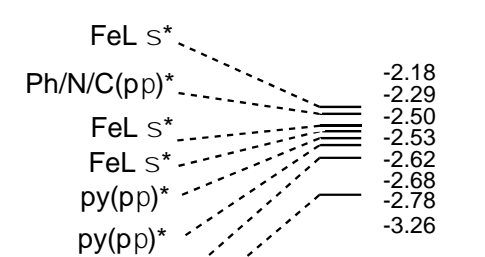

eV

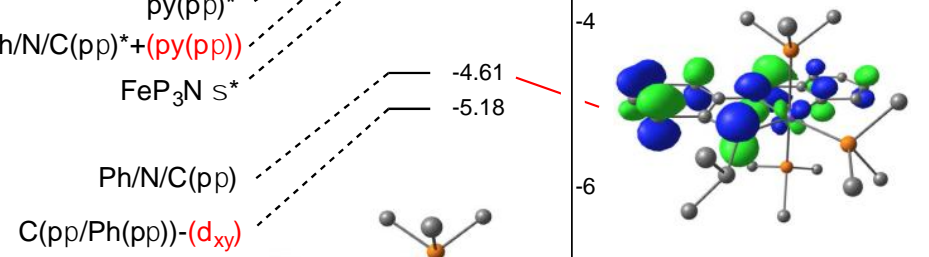

Fig. 1.

Truncated molecular orbital diagram of $\left[m e r-\left\{\kappa-\mathrm{C}, \mathrm{N}, \mathrm{C}-\left(2-\mathrm{C}_{6} \mathrm{H}_{4}\right) \mathrm{CH}=\mathrm{N}\left(1,2-\mathrm{C}_{6} \mathrm{H}_{4}\right) \mathrm{C}\left({ }^{\mathrm{i}} \mathrm{Pr}\right)=\right\}\right.$ $\left.\mathrm{Fe}\left(\mathrm{PMe}_{3}\right)_{3}\right]\left[\mathrm{BAr}_{4}^{\mathrm{F}}\right]\left(1, \mathrm{P}^{\prime}=\mathrm{PMe}_{3}\right)$, including illustrations of four occupied and the first two unoccupied orbitals (principal components in black; minor in red). Optimized geometry $(M 06 / 6-31+G(d))$ shown in upper left; bond lengths in $\AA$.

model was deemed a reasonable representation. In general, the diagram illustrates highly admixed iron/ligand orbitals derived from component orbitals of similar energy.

A formal Fe(IV) designation of 1 would afford a $\mathrm{d}^{4}$ designation, but the occupied orbitals in Fig. 1 indicate significant ambiguity. Two of the orbitals are essentially $d_{y z} \pm N(p \pi)$, such that the d-orbital is spread within bonding and anti-bonding interactions of the imine nitrogen, and its conjugation with the iminophenyl and pyridine groups. The intimate mixing of $d_{y z}$ with the chelate $\pi$-system through its imine reveals how low in energy the metal orbitals have become, presumably due to the large positive formal charge on the metal ion. Mössbauer spectral parameters of 1 are nearly identical to its Fe(II) vinyl precursor, [7] indicating a similar amount of electron density on iron, and the molecular orbital 
diagram corroborates this observation. Two additional electrons are in $d_{x z}$, but two electrons are also in an orbital that is $\mathrm{Fe}=\mathrm{C} \pi$-bonding, yet largely $\mathrm{d}_{\mathrm{xy}}$ in composition. Its ligand-based partner is empty, and roughly $3.5 \mathrm{eV}$ above in energy, showing that the positive charge in this cation is localized squarely on the carbon of the alkylidene, as the valence bond depiction in Fig. 2 illustrates. This is not unexpected based on the proclivity of previous $\mathrm{Cp}$-based "Fe(IV) alkylidenes" to undergo cyclopropanation reactions, [19] but not olefin metathesis.
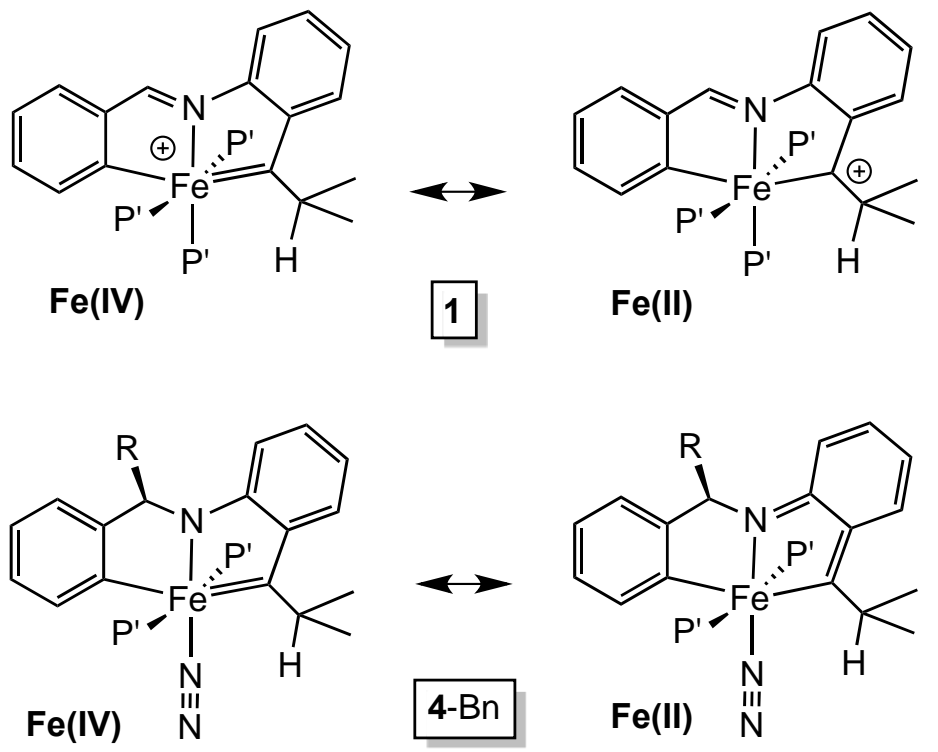

Fig. 2. Valence bond representations of the cation of $\left[\right.$ mer- $\left\{\kappa-C, N, C-\left(2-\mathrm{C}_{6} \mathrm{H}_{4}\right) \mathrm{CH}=\mathrm{N}(1,2-\right.$ $\left.\left.\left.\mathrm{C}_{6} \mathrm{H}_{4}\right) \mathrm{C}\left({ }^{\mathrm{i}} \mathrm{Pr}\right)=\right\} \mathrm{Fe}\left(\mathrm{PMe}_{3}\right)_{3}\right]\left[\mathrm{B}\left(3,5-\left(\mathrm{CF}_{3}\right)_{2}-\mathrm{C}_{6} \mathrm{H}_{3}\right)_{4}\right](1)$ and mer, trans $-\left\{\mathrm{\kappa}-\mathrm{C}, \mathrm{N}, \mathrm{C}-\left(2-\mathrm{C}_{6} \mathrm{H}_{4}\right) \mathrm{CH}(\mathrm{Bn}) \mathrm{N}\right.$ $\left(1,2-\mathrm{C}_{6} \mathrm{H}_{4}\right) \mathrm{C}\left({ }^{i} \mathrm{Pr}\right)=3 \mathrm{Fe}\left(\mathrm{PMe}_{3}\right)_{2} \mathrm{~N}_{2}(4-\mathrm{Bn})$. Molecular orbital calculations indicate the $\mathrm{Fe}(\mathrm{II})$ forms merit considerable weight in understanding the electronic structure of the "alkylidene" complexes.

2.1.2. Calculation of mer, trans- $\left\{\kappa^{-} \mathrm{C}, \mathrm{N}, \mathrm{C}-\left(2-\mathrm{C}_{6} \mathrm{H}_{4}\right) \mathrm{CH}(\mathrm{Bn}) \mathrm{N}\left(1,2-\mathrm{C}_{6} \mathrm{H}_{4}\right) \mathrm{C}\left({ }^{i} \mathrm{Pr}\right)=\right\} \mathrm{Fe}(\mathrm{PMe})_{3}(4-\mathrm{Bn})$.

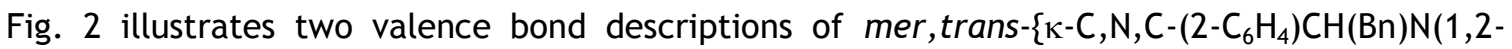
$\left.\mathrm{C}_{6} \mathrm{H}_{4}\right) \mathrm{C}(\mathrm{Pr})=3 \mathrm{Fe}\left(\mathrm{PMe}_{3}\right)_{2} \mathrm{~N}_{2}$ (4-Bn),[8] one possessing a formal $\mathrm{Fe}(\mathrm{IV})$ oxidation state, and a second featuring an $\mathrm{Fe}(\mathrm{II})$ form generated via disruption of the aromaticity of a phenyl ring. Metrics determined from a crystal structure determination of 4 - $\mathrm{Bn}$ revealed the requisite shortening of the $\mathrm{CN}$ $(1.326(2) \AA)$ and CC 


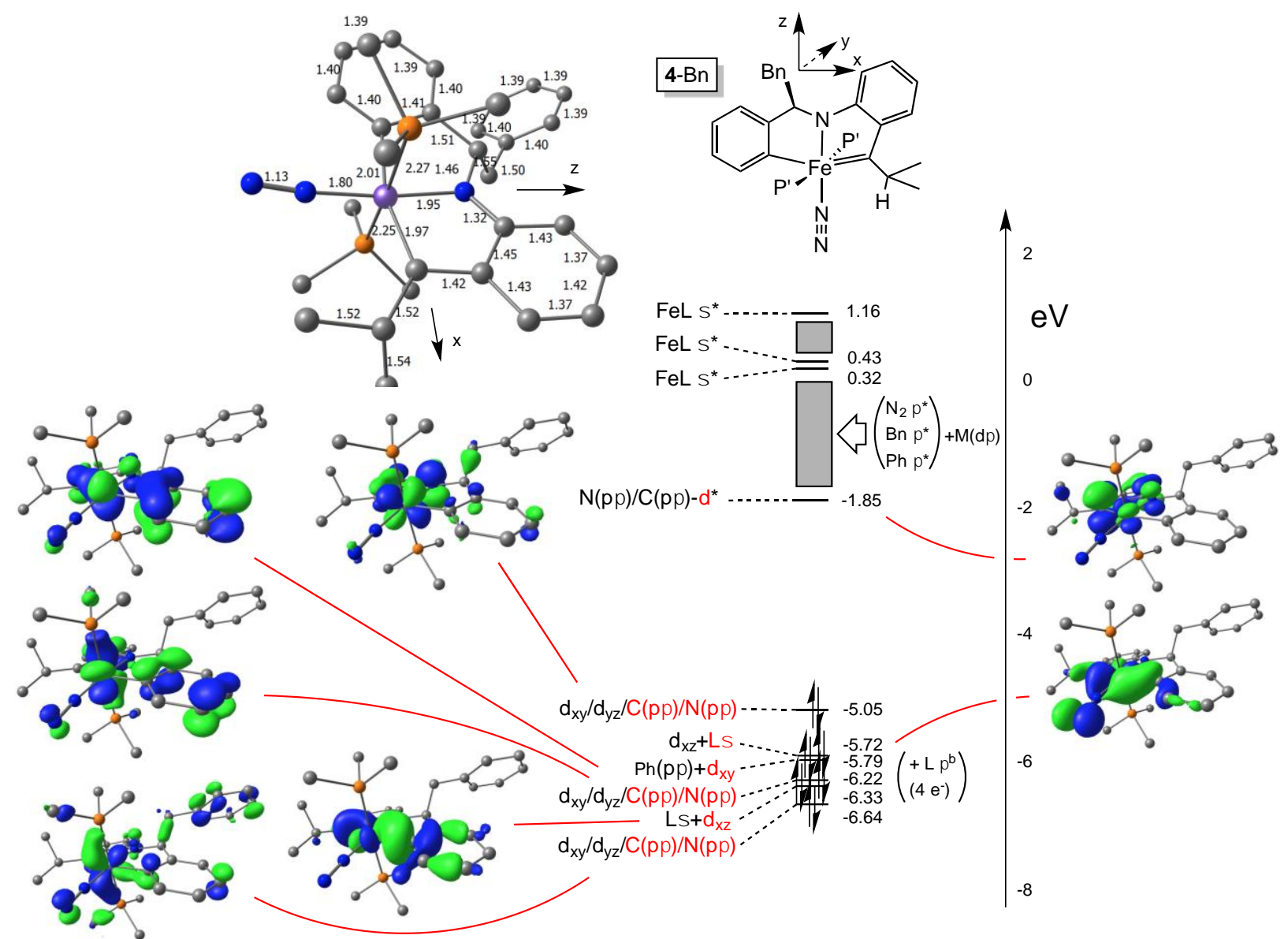

Fig. 3.

Truncated molecular orbital diagram of mer, trans $-\left\{\kappa-\mathrm{C}, \mathrm{N}, \mathrm{C}-\left(2-\mathrm{C}_{6} \mathrm{H}_{4}\right) \mathrm{CH}(\mathrm{Bn}) \mathrm{N}(1,2-\right.$ $\left.\mathrm{C}_{6} \mathrm{H}_{4}\right) \mathrm{C}\left({ }^{\prime} \mathrm{Pr}\right)=3 \mathrm{Fe}\left(\mathrm{PMe}_{3}\right)_{2} \mathrm{~N}_{2}\left(4-\mathrm{Bn}, \mathrm{P}^{\prime}=\mathrm{PMe}_{3}\right)$, including illustrations of six occupied and the first unoccupied orbitals (principal components in black; minor in red). The shaded boxes are regions of energy in which several orbitals of dominant ligand composition exist. Optimized geometry (M06/6-31+G(d)) shown in upper left; bond lengths in $\AA$.

$(1.420(2) \AA ̊)$ bonds stemming from the phenyl substituent, and a lengthy "Fe=C" distance of $1.9535(16)$

A. Calculations support the importance of the $\mathrm{Fe}(\mathrm{II})$ resonance form as the truncated molecular orbital diagram in Fig. 3 indicates.

While it is understandable to view the " $\mathrm{Fe}=\mathrm{C}$ " and Fe-amide bonds as separate interactions, the low symmetry of 4-Bn and the conjugation supported by the phenyl group render them dependent, as Fig. 3 reveals. At least three occupied and one unoccupied orbitals are linear combinations of $d_{x y}, d_{y z}$, $C(p \pi)$, and $N(p \pi)$, a consequence of the $1,2-{ }^{i} P r C, N R-C_{6} H_{4}$ moiety interacting as a unit. It is difficult to ascertain the $d$-count of the complex since the six occupied orbitals that have significant metal 
composition are highly admixed with chelate orbitals. [8] There is no obvious "Fe=C" $\pi^{*}$-orbital, although the unoccuppied orbital at $-1.85 \mathrm{eV}$ has the correct phase to be interpreted as a largely ligandcomprised version. Even the $d_{x z}$ orbital is partitioned into metal- and ligand-based combinations that have substantial $\sigma^{\mathrm{b}}$-character. It is difficult to reconcile the bonding combinations with a " $\mathrm{d}^{4 n}$ configuration crucial for olefin metathesis given the covalency in the system, as manifested by the highly admixed molecular orbitals. It is clear that the Fe(II) resonance form is at least as important, if not the dominant component, of the electronic ground state of $4-\mathrm{Bn}$.

\subsection{Attempts to Synthesize $L_{n} F e=C H R$.}

\subsubsection{General.}

The general synthetic approach to $L_{n} \mathrm{Fe}=\mathrm{CHR}$ is illustrated in Scheme 2, where protonation of a vinyl complex [9-13] is envisaged to occur at the $\beta$-position of the alkenyl after metalation of a tridentate ligand via Kharsch's complex, cis- $\left(\mathrm{Me}_{3} \mathrm{P}\right)_{4} \mathrm{FeMe}_{2},[20]$ a well-utilized $\mathrm{C}-\mathrm{H}$ activation reaction. $[7,8,16,21-23]$ Generation of the chelate via a condensation process from aldehyde and amine
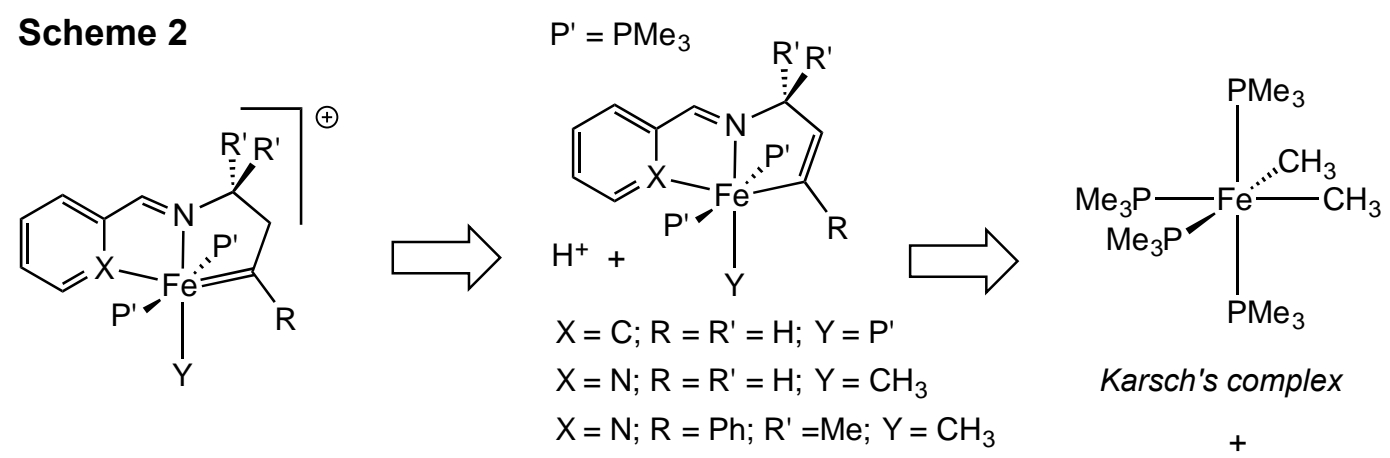

Karsch's complex
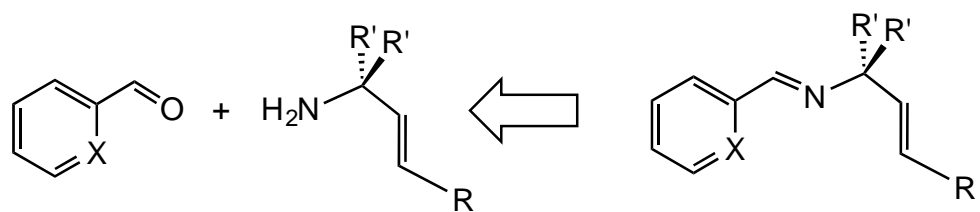
precursors is a standard route. In this instance, problems with routes to benzaldehyde derivatives prompted an initial look at pyridine-carboxaldehyde-based chelates, and these are reported herein.

\section{Scheme 3}

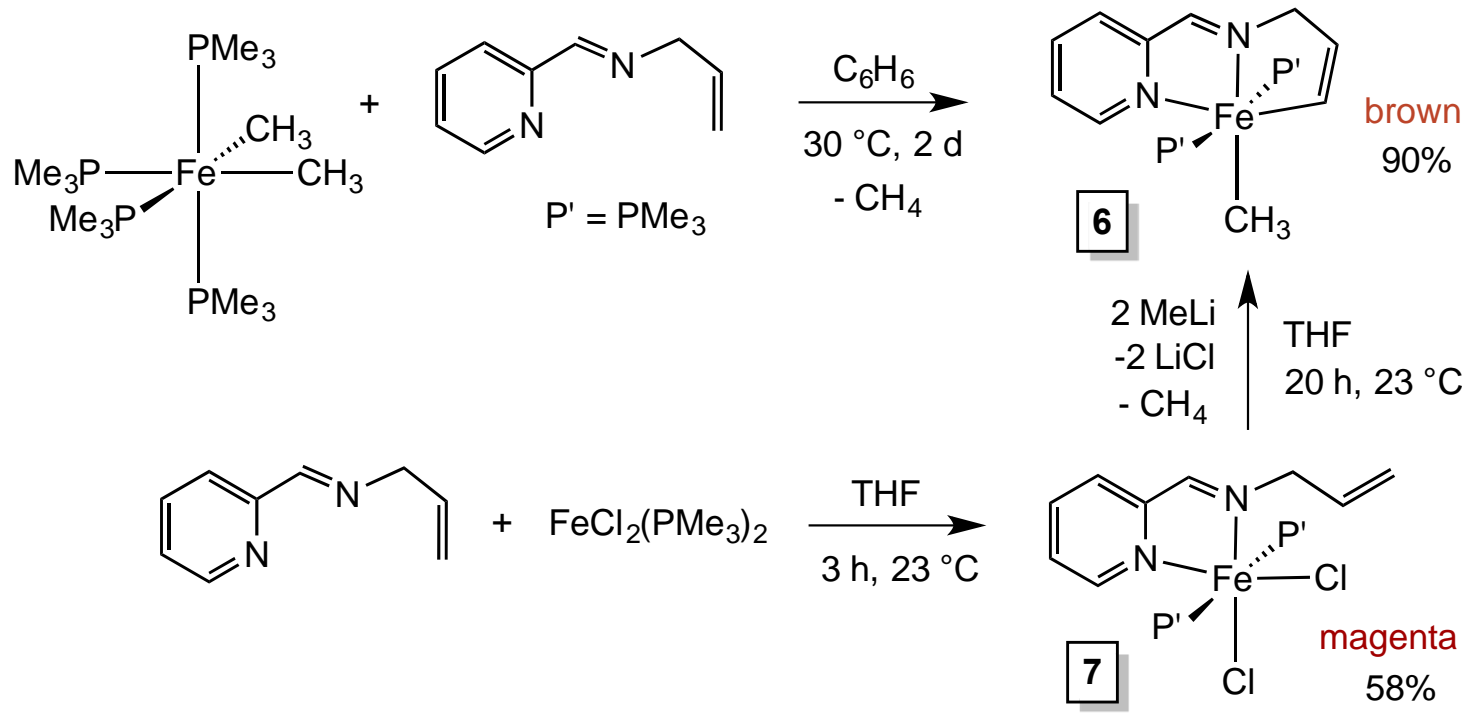

\subsubsection{Synthesis of mer, trans- $\left\{\kappa^{3}-\mathrm{N}, \mathrm{N}, \mathrm{C}-2-\mathrm{py}-\mathrm{CH}=\mathrm{NCH}_{2} \mathrm{CH}=\mathrm{CH}\right\} \mathrm{Fe}\left(\mathrm{PMe}_{3}\right)_{2} \mathrm{CH}_{3}(6)$.}

Treatment of cis- $\left(\mathrm{Me}_{3} \mathrm{P}\right)_{4} \mathrm{FeMe}_{2}$ [20] with 2-py- $\mathrm{CH}=\mathrm{NCH}_{2} \mathrm{CH}=\mathrm{CH}_{2}$ at $30{ }^{\circ} \mathrm{C}$ for $2 \mathrm{~d}$ proceeded with vinyl $\mathrm{CH}$-activation and methane loss to afford mer, trans- $\left\{\kappa^{3}-\mathrm{N}, \mathrm{N}, \mathrm{C}-(2-\mathrm{py}) \mathrm{CH}=\mathrm{NCH}_{2} \mathrm{CH}=\mathrm{CH}\right\}$ $\mathrm{Fe}\left(\mathrm{PMe}_{3}\right)_{2} \mathrm{CH}_{3}(6)$ in excellent yield $(90 \%)$. The ${ }^{1} \mathrm{H}$ NMR spectrum of 6 featured a triplet at $\delta 1.37\left(J_{\mathrm{PH}}=\right.$ $13 \mathrm{~Hz}$ ) corresponding to the $\mathrm{FeCH}_{3}$, and a singlet in the ${ }^{31} \mathrm{P}\left\{{ }^{1} \mathrm{H}\right\} \mathrm{NMR}$ spectrum at $\delta 9.04$ indicative of the mer-trans-conformation. Another route was examined as a cheaper alternative, and $\mathrm{FeCl}_{2}\left(\mathrm{PMe}_{3}\right)_{2}$ was combined with 2-py- $\mathrm{CH}=\mathrm{NCH}_{2} \mathrm{CH}=\mathrm{CH}_{2}$ for $3 \mathrm{~h}$ at $23{ }^{\circ} \mathrm{C}$ to afford the pyridine-imine complex, cis, trans(2-py- $\left.\mathrm{CH}=\mathrm{NCH}_{2} \mathrm{CH}=\mathrm{CH}_{2}\right) \mathrm{Cl}_{2}\left(\mathrm{PMe}_{3}\right)_{2}$ (7) in modest yield (58\%) as sparingly soluble magenta crystals. Dichloride 7 was used without further purification, and subsequent alkylation with MeLi in THF provided 6 amidst some impurities, hence the initial route proved to be more efficient. 


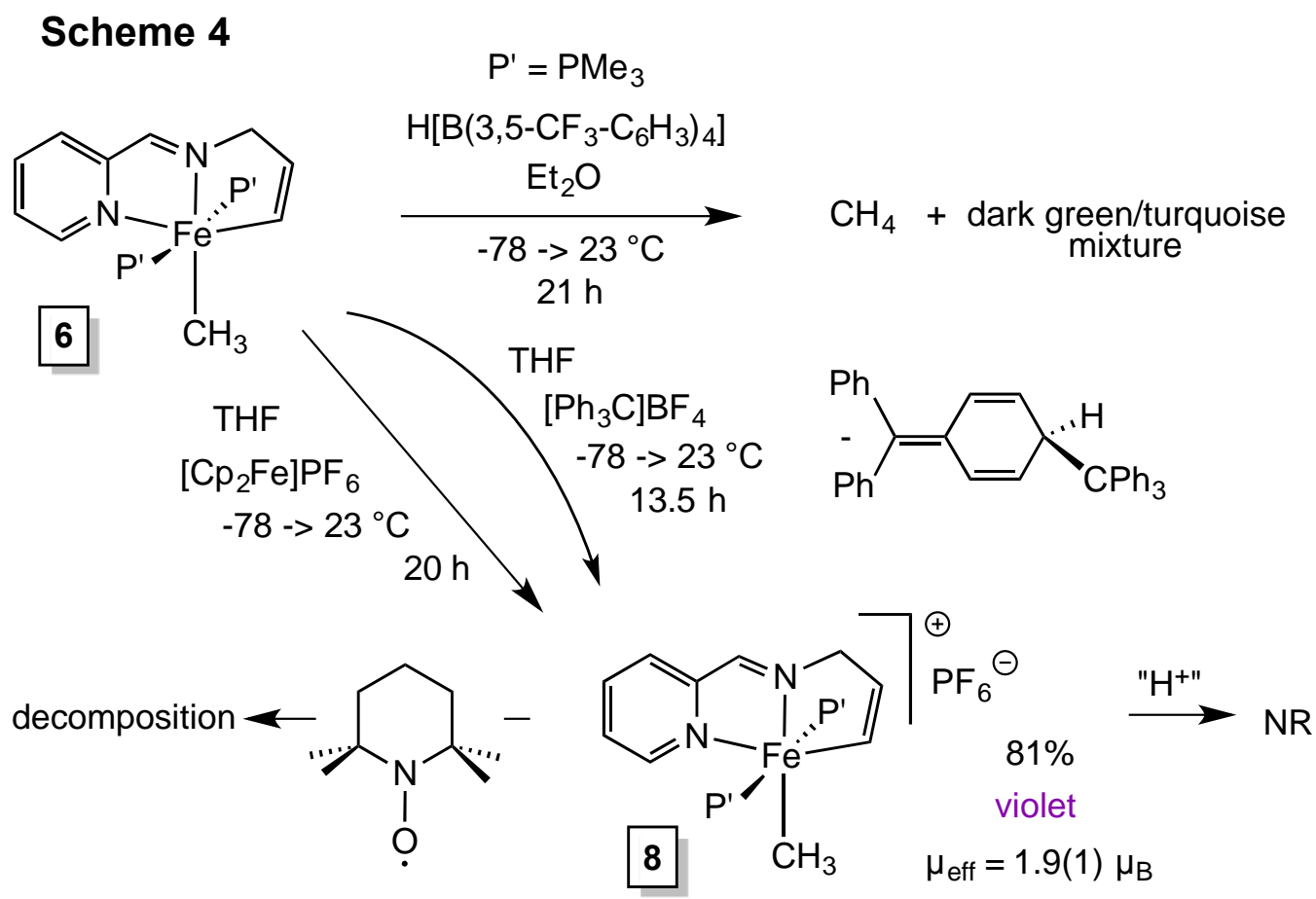

\subsubsection{Oxidations of mer, trans- $\left\{\kappa^{3}-\mathrm{N}, \mathrm{N}, \mathrm{C}-2-\mathrm{py}-\mathrm{CH}=\mathrm{NCH} \mathrm{CH}_{2} \mathrm{CH}=\mathrm{CH}\right\} \mathrm{Fe}\left(\mathrm{PMe}_{3}\right)_{2} \mathrm{CH}_{3}(6)$.}

In previous cases, protonation of vinyl-iron complexes afforded "Fe(IV)" alkylidenes, but in this instance, treatment of mer, trans $-\left\{\kappa^{3}-\mathrm{N}, \mathrm{N}, \mathrm{C}-2-\mathrm{py}-\mathrm{CH}=\mathrm{NCH}_{2} \mathrm{CH}=\mathrm{CH}\right\} \mathrm{Fe}\left(\mathrm{PMe}_{3}\right)_{2} \mathrm{CH}_{3}$ (6) with $\mathrm{H}\left[\mathrm{B}\left(3,5-\left(\mathrm{CF}_{3}\right)_{2}-\right.\right.$ $\left.\mathrm{C}_{6} \mathrm{H}_{3}\right)_{4}$ ] [24] led to a green-turquoise mixture of multiple products, and the apparent formation of methane, consistent with electrophilic cleavage of the $\mathrm{Fe}-\mathrm{CH}_{3}$ bond, a worrisome alternate process. Various proton sources, such as weakly acidic, bulky alcohols $\left(\mathrm{PhCMe}_{2} \mathrm{OH}\right)$ or phenol failed to generate any reaction, and neither did $[\mathrm{BH}] \mathrm{Cl}\left(\mathrm{B}=\right.$ lutidine, $\left.\mathrm{NEt}_{3}\right)$.

An attempt was made to abstract hydride from the methylene unit in order to prepare a totally conjugated "Fe(IV)" alkylidene, but treatment of 6 with $\left[\mathrm{Ph}_{3} \mathrm{C}\right] \mathrm{BF}_{4}$ led to the production of a paramagnetic product and Gomberg's dimer, $\left(\mathrm{Ph}_{3} \mathrm{C}\right)_{2},[25,26]$ consistent with oxidation. The addition of $\left[\mathrm{Cp}_{2} \mathrm{Fe}\right] \mathrm{PF}_{6}$ to 6 generated a similarly violet-colored product, formulated as [mer, trans- $\left\{\kappa^{3}-\mathrm{N}, \mathrm{N}, \mathrm{C}-2-\mathrm{py}-\right.$ $\left.\left.\mathrm{CH}=\mathrm{NCH}_{2} \mathrm{CH}=\mathrm{CH}\right\} \mathrm{Fe}\left(\mathrm{PMe}_{3}\right)_{2} \mathrm{CH}_{3}\right]\left[\mathrm{X}^{-}\right]\left(8, \mathrm{X}^{-}=\mathrm{BF}_{4}^{-}\right.$or $\left.\mathrm{PF}_{6}^{-}\right)$. An Evans' method [27] measurement on $3^{+}$ produced a greater than spin-only $\mu_{\text {eff }}$ of $1.9(1) \mu_{B}$, consistent with a low spin $d^{5}, \mathrm{Fe}(\mathrm{III})$ center having a modest spin-orbit contribution. [28] Attempts to mimic a hydride abstraction via the reaction of TEMPO with 8 led to degradation. 


\subsubsection{Synthesis and reactivity of mer, trans- $\left\{\kappa^{3}-\mathrm{N}, \mathrm{N}, \mathrm{C}-2-\mathrm{py}-\mathrm{CH}=\mathrm{NCH}_{2} \mathrm{CH}=\mathrm{CH}\right\} \mathrm{Fe}\left(\mathrm{PMe}_{3}\right)_{2} \mathrm{I}$ (9).}

The likelihood that the Fe-Me functionality is protonated by $\mathrm{H}\left[\mathrm{BAr}_{4}^{\mathrm{F}}\right]$, instead of electrophilic attack at the $\beta$-vinyl position, prompted its replacement. Treatment of mer,trans $-\left\{\kappa^{3}-N, N, C-2-p y-\right.$ $\left.\mathrm{CH}=\mathrm{NCH}_{2} \mathrm{CH}=\mathrm{CH}\right\} \mathrm{Fe}\left(\mathrm{PMe}_{3}\right)_{2} \mathrm{CH}_{3}(6)$ with $\mathrm{I}_{2}$ afforded the corresponding iodide, mer, trans- $\left\{\kappa^{3}-\mathrm{N}, \mathrm{N}, \mathrm{C}-2-\mathrm{py}-\right.$ $\left.\mathrm{CH}=\mathrm{NCH}_{2} \mathrm{CH}=\mathrm{CH}\right\} \mathrm{Fe}\left(\mathrm{PMe}_{3}\right)_{2} \mathrm{I}(9)$, in modest yield (26\%) as brown crystals. The ${ }^{1} \mathrm{H}$ NMR spectrum of the reaction mixture conducted in THF- $d_{8}$ was consistent with a $C_{\mathrm{s}}$ structure (e.g., ${ }^{31} \mathrm{P}\left\{{ }^{1} \mathrm{H}\right\}, \delta-1.16$ ) accompanied by signals tentatively assigned to ethane and methane in a 3.6:1 ratio, but no $\mathrm{CH}_{3} \mathrm{I}$ was observed. An alternate route featuring metalation of 2-py- $\mathrm{CH}=\mathrm{NCH}_{2} \mathrm{CH}=\mathrm{CH}_{2}$ with cis- $\left(\mathrm{Me}_{3} \mathrm{P}\right)_{4} \mathrm{Fe}\left(\mathrm{CH}_{3}\right) \mathrm{I}$ $[29,30]$ afforded an intermediate tentatively formulated as trans- $\left\{\kappa^{2}-\mathrm{N}, \mathrm{N}-2-\mathrm{py}-\mathrm{CH}=\mathrm{NCH} \mathrm{CH}_{2}=\mathrm{CH}_{2}\right\} \mathrm{Fe}$ $\left(\mathrm{PMe}_{3}\right)_{2}\left(\mathrm{CH}_{3}\right) \mid(10)$ on the basis of broad ${ }^{1} \mathrm{H}$ and ${ }^{31} \mathrm{P}\left\{{ }^{1} \mathrm{H}\right\}$ NMR spectra consistent with a $\mathrm{C}_{\mathrm{s}}$ species. Continued thermolysis generated $9(54 \%)$, but its purity was only $~ 50 \%$, and the route was abandoned given the inability to convert 9 to desired species.

\section{Scheme 5}

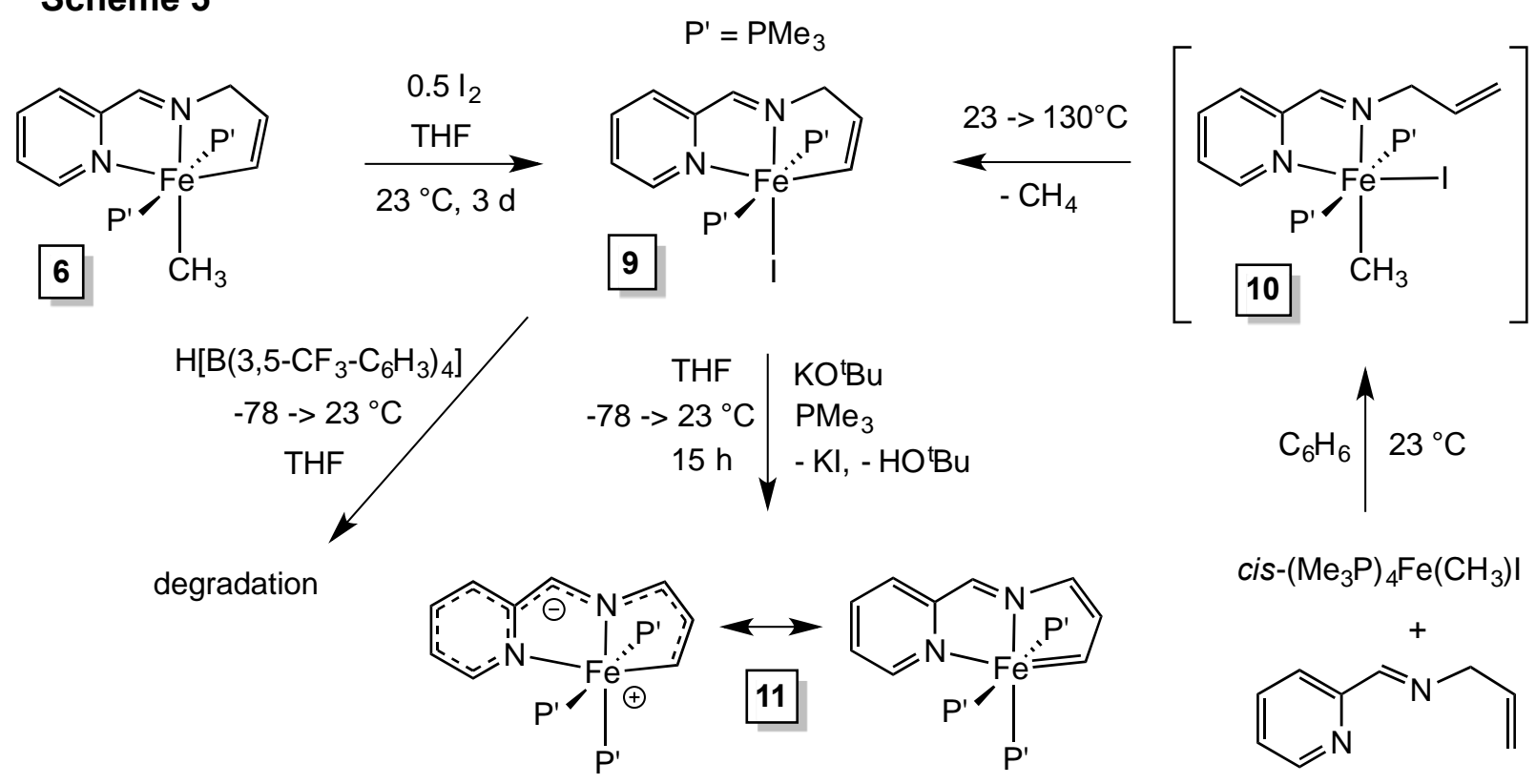


Attempts to protonate iodide 9 with the standard $H\left[\mathrm{BAr}_{4}{ }_{4}\right]$ protocol failed, but one of the products in the resulting mixture possessed a mer- $\left(\mathrm{PMe}_{3}\right)$ spectral signature $(\mathrm{ABB})$ in the ${ }^{31} \mathrm{P}$ NMR spectrum, indicative of disproportionation, perhaps due to cleavage of the Fe-vinyl bond. In an attempt to replace the iodide in $\mathbf{9}$ with the sterically larger tert-butoxide, another ABB' pattern was observed. Since this also was indicative of disproportionation, 9 was treated with $\mathrm{KO}^{\mathrm{t}} \mathrm{Bu}$ in the presence of $\mathrm{PMe}_{3}$ to cleanly (>95\%) afford the formal Fe(II) alkylidene, mer-\{k ${ }^{3}-\mathrm{N}, \mathrm{N}, \mathrm{C}$-(2-pyridyl)CHNCHCHCH$\} \mathrm{Fe}\left(\mathrm{PMe}_{3}\right)_{3}$ (11) via deprotonation of a methylene proton. The "alkylidene" proton was observed at $\delta 6.93\left({ }^{3} J_{\mathrm{HP2}}=\right.$ $\left.2,{ }^{3} J_{\mathrm{PH}}=3,{ }^{3} J_{\mathrm{HH}}\right)$ in the ${ }^{1} \mathrm{H}$ NMR spectrum and at $\delta 189.39\left(\mathrm{~J}_{\mathrm{HP} 2}=25 \mathrm{~Hz}, J_{\mathrm{HP}}=12 \mathrm{~Hz}\right)$ in the ${ }^{13} \mathrm{C}\left\{{ }^{1} \mathrm{H}\right\}$ spectrum, values that are more attributable to a vinyl group than a MCHR unit. For example, the Fe$\mathrm{CH}=$ group in 9 exhibits a ${ }^{13} \mathrm{C}\left\{{ }^{1} \mathrm{H}\right\}$ NMR spectral signal at $\delta 172.47$ (t, $33 \mathrm{~Hz}$ ). In Hoffmann's alkylidene analysis,[6] octahedral complexes with $d^{n}(n \geq 4)$ should not possess metal-carbon double bonds, hence the structure -- both geometric and electronic -- of 11 was examined in detail.

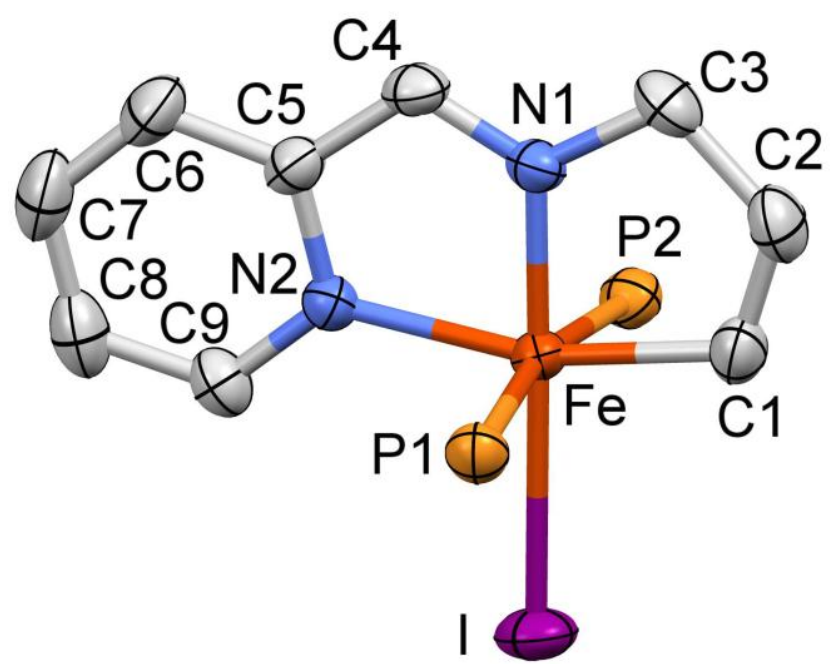

Fig. 4. Molecular view of mer,trans- $\left\{\kappa^{3}-\mathrm{N}, \mathrm{N}, \mathrm{C}-(2\right.$-pyridyl $\left.) \mathrm{CHNCH}_{2} \mathrm{CHCH}\right\} \mathrm{Fe}\left(\mathrm{PMe}_{3}\right)_{2} \mathrm{I}$ (9) with methyl groups of $\mathrm{PMe}_{3}$ removed for clarity. Selected interatomic distances $(\AA)$ and angles $\left({ }^{\circ}\right)$ : Fe-N1, 1.8514(16); Fe-N2, 2.0129(17); Fe-C1, 1.961(2); Fe-P1, 2.2472(7); Fe-P2, 2.2461(7); Fe-I, 2.7132(5); C1-C2, 1.332(3); C2-C3, 1.490(3); N1-C3, 1.470(3); N1-C4, 1.307(3); C4-C5, 1.428(3); N2-C5, 1.371(3); N2-C9, 1.347; C5-C6, 1.396(3); C6C7, 1.369(3); C7-C8, 1.385(4); C8-C9, 1.373(3); N1-Fe-N2, 80.37(7); N1-Fe-C1, 82.34(9); N1-Fe-P1, 93.94(5); N1-Fe-P2, 95.33(5); N1-Fe-I, 178.78(5); N2-Fe-C1, 162.49(9); N2Fe-P1, 93.94(5); N2-Fe-P2, 96.72(5); N2-Fe-I, 98.54(5); C1-Fe-P1, 86.21(7); C1-Fe-P2, 87.58(7); C1-Fe-I, 98.73(7); P1-Fe-P2, 168.06(2); P1-Fe-I, 85.56(2); P2-Fe-I, 85.32(2); Fe-C1-C2, 115.01(17); C1-C2-C3, 117.13(19); N1-C3-C2, 105.89(17); C3-N1-C4, 
120.22(17); Fe-N1-C3, 119.54(14); Fe-N1-C4, 120.21(14); N1-C4-C5, 113.97(17); C4-C5N2, 113.02(17); C5-N2-C9, 116.61(18); Fe-N2-C5, 112.33(13); Fe-N2-C9, 130.91(15).

\subsection{Single Crystal X-ray Structure Determinations \\ 2.3.1. mer, trans- $\left\{\kappa^{3}-\mathrm{N}, \mathrm{N}, \mathrm{C}-(2-\mathrm{pyridyl}) \mathrm{CHNCH}_{2} \mathrm{CHCH}\right\} \mathrm{Fe}\left(\mathrm{PMe}_{3}\right)_{2} \mathrm{l}$ (9).}

Prior to analysis of the "Fe(II) alkylidene", a bona fide example of a standard Fe(II) vinyl species was sought for comparison, hence mer, trans- $\left\{\kappa^{3}-\mathrm{N}, \mathrm{N}, \mathrm{C}-2-\mathrm{py}-\mathrm{CH}=\mathrm{NCH}_{2} \mathrm{CH}=\mathrm{CH}\right\} \mathrm{Fe}\left(\mathrm{PMe}_{3}\right)_{2} \mathrm{I}$ (9) was assessed via a single crystal X-ray structure determination. The geometry of pseudo-octahedral 9 is given in Fig. 4, and pertinent metrics are listed in the caption. The Fe-C(vinyl) distance of 1.961(2) $\AA$ is $\geq 0.06 \AA$ longer than related " $\mathrm{Fe}=\mathrm{C}$ " bonds in previously analyzed alkylidene cations,[7] and $\geq 0.06$ shorter than $\mathrm{Fe}-\mathrm{C}(\mathrm{Ar})$ bond lengths, but essentially the same as the "Fe=C" distances in 4-Bn and 5-Me (Scheme 1).[8] The remainder of the chelate metrical data matches the valence bond description, with $\mathrm{d}(\mathrm{C} 1-\mathrm{C} 2)=1.332(3) \AA$, and $\mathrm{d}(\mathrm{N} 1-\mathrm{C} 4)=1.307(3) \AA$, in accord with double bonds. Bond lengths of $\mathrm{C} 2-\mathrm{C} 3$ $(1.490(3) \AA)$ and $\mathrm{N} 1-\mathrm{C} 3(1.470(3) \AA)$ correspond to $\mathrm{C}\left(\mathrm{sp}^{2}\right)-\mathrm{X}\left(\mathrm{sp}^{2}\right)$ single bonds,[31] and the pyridine distances are normal. As is typical for these tridentate chelates, the N2-Fe-C1 angle of $162.49(9)^{\circ}$ indicates its "bite" to be less than perfect, with the short $d(\mathrm{Fe}-\mathrm{N} 1)$ of $1.8514(16) \AA$ a likely consequence. The $\mathrm{N} 1-\mathrm{Fe}-\mathrm{P}_{\text {cis }}$ angles average $94.6(10)^{\circ}$, as the phosphines are slightly tipped toward the iodide, perhaps indicative of the $N(p \pi)$ influence on the filled $d_{y z}$ orbital that is backbonding with the $\mathrm{PMe}_{3}$ ligands. The remainder of the distances and angles show no surprises.

\subsection{2. $\operatorname{mer}-\left\{\kappa^{3}-\mathrm{N}, \mathrm{N}, \mathrm{C}-(2-\mathrm{pyridyl}) \mathrm{CHNCHCHCH}\right\} \mathrm{Fe}\left(\mathrm{PMe}_{3}\right)_{3}(11)$.}

The molecular structure of the "Fe(II) alkylidene", mer-\{ $\left.\kappa^{3}-\mathrm{N}, \mathrm{N}, \mathrm{C}-(2-\mathrm{pyridyl}) \mathrm{CHNCHCHCH}\right\}$ $\mathrm{Fe}\left(\mathrm{PMe}_{3}\right)_{3}(11)$, is given in Fig. 5, and selected metrics are listed in the caption. The critical Fe-C1 distance of $1.9602(17) \AA$ is essentially the same as its precursor Fe(II) vinyl iodide, hence it is best construed as a single bond to an $\mathrm{sp}^{2}$-carbon. In corroboration, the C1-C2 distance of $1.349(3) \AA$ is 


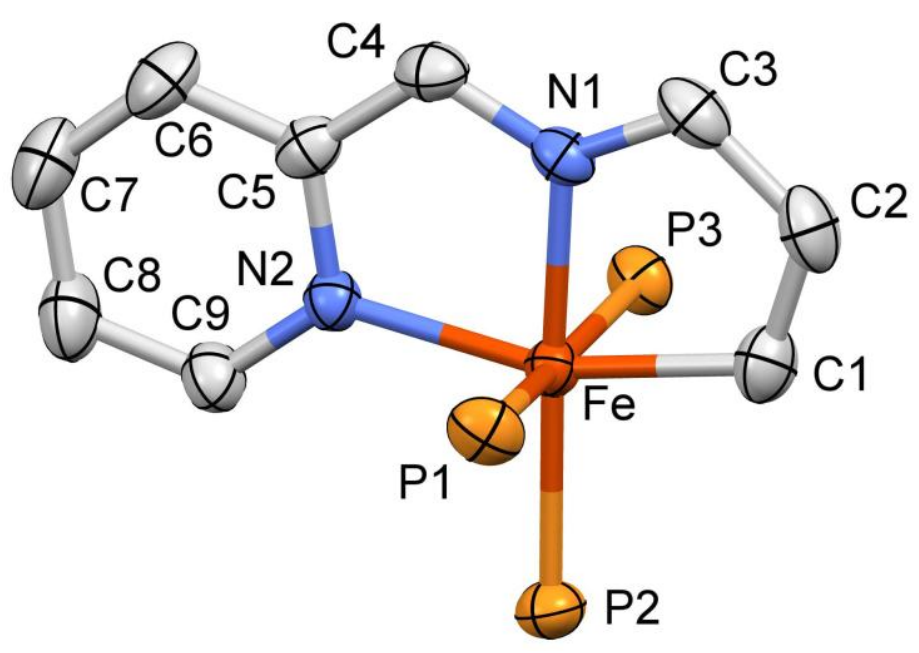

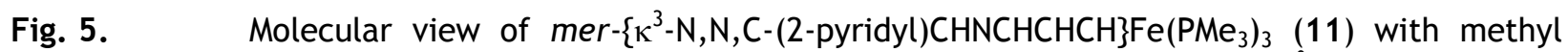
groups of $\mathrm{PMe}_{3}$ removed for clarity. Selected interatomic distances $(\AA)$ and angles $\left({ }^{\circ}\right)$ : Fe-N1, 1.9534(14); Fe-N2, 2.0486(13); Fe-C1, 1.9602(17); Fe-P1, 2.2305(5); Fe-P2, 2.2207(5); Fe-P3, 2.2391(5); C1-C2, 1.349(3); C2-C3, 1.426(3); N1-C3, 1.315(2); N1-C4, 1.368(2); C4-C5, 1.384(2); N2-C5, 1.399(2); N2-C9, 1.346(2); C8-C9, 1.376(3); C7-C8, 1.391(3); C6-C7, 1.356(3); C5-C6, 1.418(2); P-C (ave), 1.835(7); N1-Fe-N2, 80.98(5); N1-Fe-C1, 80.44(7); N1-Fe-P1, 86.44(4); N1-Fe-P2, 177.71(4); N1-Fe-P3, 87.13(4); N2$\mathrm{Fe}-\mathrm{C} 1,161.42(7)$; N2-Fe-P1, 91.42(4); N2-Fe-P2, 101.31(4); N2-Fe-P3, 91.98(4); C1-FeP1, 87.35(6); C1-Fe-P2, 97.27(6); C1-Fe-P3, 87.18(5); P1-Fe-P2, 93.63(2); P1-Fe-P3, 172.17(2); P2-Fe-P3, 92.62(2); Fe-C1-C2, 114.34(14); Fe-N2-C9, 131.56(12), Fe-N2-C5, 111.17(10); Fe-N1-C3, 116.39(13); Fe-N1-C4, 115.74(11); C1-C2-C3, 114.78(14); N1-C3C2, 114.03(16); C3-N1-C4, 127.86(16); N1-C4-C5, 115.88(15); N2-C5-C4, 116.22(15).

consistent with a long double bond, and the $\mathrm{d}(\mathrm{C} 2-\mathrm{C} 3)$ of $1.426(3) \AA$ is shorter than expected, suggesting that the backbone of the chelate is a delocalized anion. The $\mathrm{d}(\mathrm{N} 1-\mathrm{C} 3)$ of $1.315(2) \AA$ and $\mathrm{d}(\mathrm{N} 1-\mathrm{C} 4)$ of $1.368(2) \AA$, correspond to an asymmetric 2 -azaallyl unit (e.g., $\mathrm{d}(\mathrm{C}-\mathrm{N})_{\text {ave }} \sim 1.35 \AA$ ), [15] while the C4-C5 bond length of $1.384(2) \AA$ is in between that of $\mathrm{C}\left(\mathrm{sp}^{2}\right)-\mathrm{C}\left(\mathrm{sp}^{2}\right)$ single and double bonds. Pyridine N2-C5 and C4-C5 distances of 1.399(2) and 1.418(2) $\AA$ are slightly longer than normal,[31] indicative of some delocalization of anionic charge into the ring. The chelate N2-Fe-C1 angle of $161.42(7)$ is again substantially less than $180^{\circ}$, and $\mathrm{d}(\mathrm{Fe}-\mathrm{N} 1)$ is quite short $(1.9534(14) \AA)$ relative to $\mathrm{d}(\mathrm{Fe}-\mathrm{N} 2)=2.0486(13) \AA$, but significantly longer than the corresponding distance in the vinyl-iodide complex (9). The chelate C3-N1-C4 angle is $127.86(16)^{\circ}$, which is more open than the corresponding $120.22(17)^{\circ}$ angle in 9 , presumably due to the delocalization of charge throughout the chelate backbone. In this complex, the trans-PMe $\mathrm{PM}_{3}$ groups are tipped slightly away from the unique $\mathrm{PMe}_{3}$, as expected on the basis of steric interactions. 


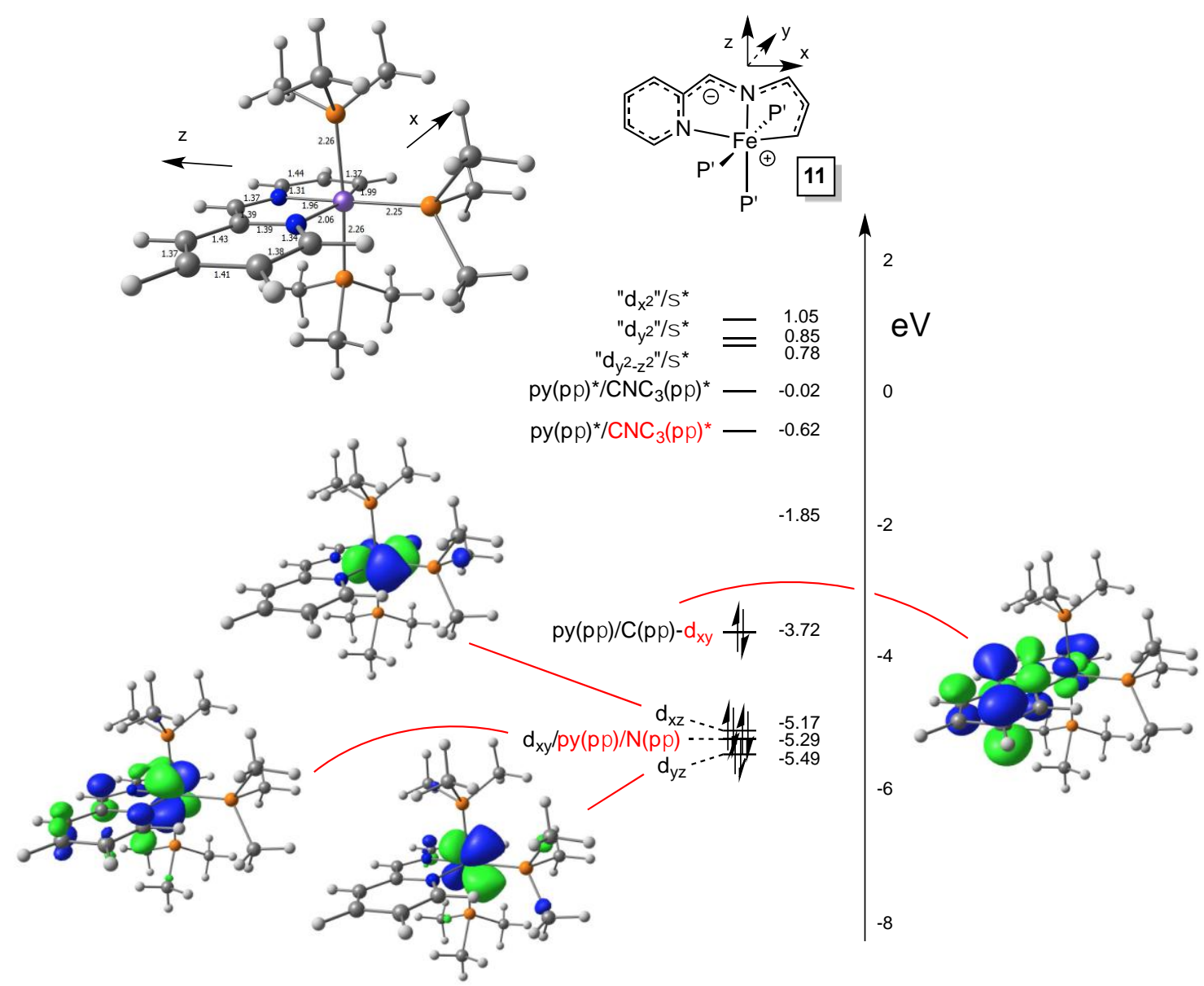

Fig. 6. Truncated molecular orbital diagram of $\operatorname{mer}-\left\{\mathrm{K}^{3}-\mathrm{N}, \mathrm{N}, \mathrm{C}-(2\right.$-pyridyl $\left.) \mathrm{CHNCHCHCH}\right\}$ $\mathrm{Fe}\left(\mathrm{PMe}_{3}\right)_{3}\left(11, \mathrm{P}^{\prime}=\mathrm{PMe}_{3}\right)$, including illustrations of four occupied orbitals (principal components in black; minor in red). Optimized geometry $(\mathrm{M06/6-31+G(d))} \mathrm{shown} \mathrm{in}$ upper left; bond lengths in $\AA$.

\subsection{Electronic Structure of mer- $\left\{\kappa^{3}-\mathrm{N}, \mathrm{N}, \mathrm{C}-(2-\right.$ pyridyl) $\mathrm{CHNCHCHCH}\} \mathrm{Fe}\left(\mathrm{PMe}_{3}\right)_{3}$ (11).}

The electronic structure of mer-\{k $\kappa^{3}-\mathrm{N}, \mathrm{N}, \mathrm{C}-(2-$ pyridyl) $\mathrm{CHNCHCHCH}\} \mathrm{Fe}\left(\mathrm{PMe}_{3}\right)_{3}$ (11) was explored via calculations, and the truncated molecular orbital diagram in Fig. 6 illustrates the results. The calculated metric parameters of 11 are within $0.03 \AA$ of the distances from the X-ray crystallographic analysis, and, like the structure, portray an $\mathrm{Fe}(\mathrm{II})$ complex with an $\mathrm{Fe}-\mathrm{C}\left(\mathrm{sp}^{2}\right)$ single 
bond. The three lowest energy orbitals are the standard " $t_{2 g}$ " set of an octahedral species, i.e., $d_{y z}, d_{x y}$ and $d_{x z}$, with a very small amount of chelate $\pi$-orbitals admixed. The HOMO in the system is a chelatebased $\pi^{*}$-orbital with a small amount of $d_{x y}$, but not enough to warrant an $\mathrm{Fe}=\mathrm{C}\left(\pi^{*}\right)$ designation. In other words, the complex is an Fe(II) $d^{6}$ species with an iron-sp ${ }^{2}$-carbon bond akin to a vinyl, and a delocalized chelate anion. The FeL $\sigma^{*}$ orbitals shown have enough ligand character that the " $e_{g}$ set" is spread over the three axes and three orbitals, and the low energy unoccupied orbitals are ligand $\pi^{*}$.

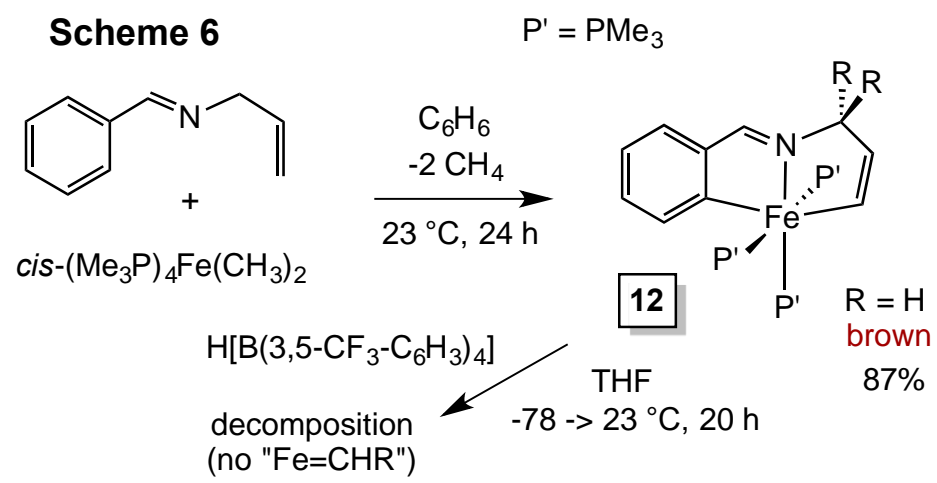

$$
\mathrm{R}^{\prime}=\mathrm{H}
$$

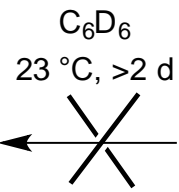

$\mathrm{R}^{\prime}=\mathrm{Ph}$

$\mathrm{C}_{6} \mathrm{D}_{6}$

$23^{\circ} \mathrm{C}, 24 \mathrm{~h}$

$35^{\circ} \mathrm{C}, 4 \mathrm{~h}$

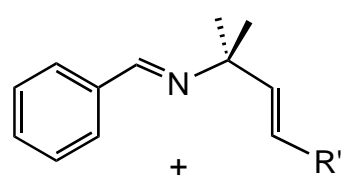

cis- $\left(\mathrm{Me}_{3} \mathrm{P}\right)_{4} \mathrm{Fe}\left(\mathrm{CH}_{3}\right)_{2}$

\subsection{A Return to a Phenyl Substituent; Attempts to Synthesize at $L_{n} \mathrm{Fe}=\mathrm{CPh}(R)$.}

Treatment of cis- $\left(\mathrm{Me}_{3} \mathrm{P}\right)_{4} \mathrm{Fe}\left(\mathrm{CH}_{3}\right)_{2}$ with $\mathrm{PhCH}=\mathrm{NCH}_{2} \mathrm{CH}=\mathrm{CH}_{2}$ afforded the double $\mathrm{CH}$-activation product, [16,23] brown mer- $\left\{\kappa^{3}-\mathrm{C}, \mathrm{N}, \mathrm{C}-\left(2-\mathrm{C}_{6} \mathrm{H}_{4}\right) \mathrm{CH}=\mathrm{NCH}_{2} \mathrm{CH}=\mathrm{CH}\right\} \mathrm{Fe}\left(\mathrm{PMe}_{3}\right)_{3} \quad$ (12) in $87 \%$ yield, but subsequent treatment with $\mathrm{H}\left[\mathrm{BAr}_{4}{ }_{4}\right]$ failed to produce material with spectral parameters consistent with protonation at the $\beta$-vinyl position (Scheme 6). Indications of disproportionation were revealed by ${ }^{1} \mathrm{H}$ NMR analysis, and it was reasoned that olefin isomerization might be an issue, so a gem-dimethyl variant was prepared. Since metalation with trans $-\mathrm{PhCH}=\mathrm{NCH}_{2} \mathrm{CH}=\mathrm{CHPh}$ was already reported, [7] attempts to metalate trans- $\mathrm{PhCH}=\mathrm{NC}(\mathrm{Me})_{2} \mathrm{CH}=\mathrm{CHPh}$ were conducted, but these surprisingly failed.

The simple explanation that gem-dimethyl substitution as indicated in Scheme 6 obviated metalation due to steric influences was proved questionable by the utilization of trans-(2py) $\mathrm{CH}=\mathrm{NCH}_{2} \mathrm{CH}=\mathrm{CHPh}$, as Scheme 7 reveals. Metalation of this chelate with cis- $\left(\mathrm{Me}_{3} \mathrm{P}\right)_{4} \mathrm{Fe}\left(\mathrm{CH}_{3}\right)_{2}$ afforded dark violet mer, trans- $\left\{\kappa^{3}-\mathrm{N}, \mathrm{N}, \mathrm{C}-(2-\mathrm{py}) \mathrm{CH}=\mathrm{NC}(\mathrm{Me})_{2} \mathrm{CH}=\mathrm{CH}\right\} \mathrm{Fe}\left(\mathrm{PMe}_{3}\right)_{2} \mathrm{CH}_{3}$ (13) in $65 \%$ yield. Presumably, 
the additional binding site provided by the pyridine helps orient the chelate and allows metalation to take place on a timescale that is faster than the intrinsic instability of Karsch's dimethyl iron complex. Unfortunately, while the gem-dimethyl substitution prevents simple olefin isomerization,

\section{Scheme 7}
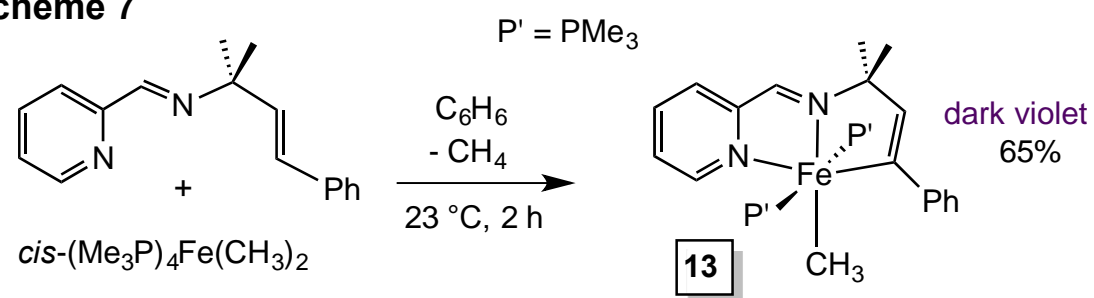

subsequent protonation with $\mathrm{H}\left[\mathrm{BAr}_{4}{ }_{4}\right]$ released methane instead of $\beta$-vinyl protonation, generating a violet material with the tentative composition of $\left[\left\{\kappa^{3}-\mathrm{N}, \mathrm{N}, \mathrm{C}-(2-\mathrm{py}) \mathrm{CH}=\mathrm{NC}(\mathrm{Me})_{2} \mathrm{CH}=\mathrm{CH}\right\} \mathrm{Fe}\left(\mathrm{PMe}_{3}\right)_{2}\right]\left[\mathrm{BAr}{ }_{4}\right]$ (14) in roughly $70 \%$ yield. Identification of 14 as either a five coordinate complex or solvate proved inplausible due to its proclivity to bind ubiquitous dinitrogen, hence the $\mathrm{N}_{2}$-adduct [mer,trans- $\left\{\kappa^{3}\right.$ $\left.\left.\mathrm{N}, \mathrm{N}, \mathrm{C}-(2-\mathrm{py}) \mathrm{CH}=\mathrm{NC}(\mathrm{Me})_{2} \mathrm{CH}=\mathrm{CH}\right\} \mathrm{Fe}\left(\mathrm{PMe}_{3}\right)_{2} \mathrm{~N}_{2}\right]\left[\mathrm{BAr}_{4}\right]$ (15) was isolated. The IR spectrum of 15 showed an absorption at $2116 \mathrm{~cm}^{-1}$ corresponding to the $v(\mathrm{NN})$ stretch, $[7,23]$ consistent with a cationic center, and a singlet at $\delta 9.10$ in the ${ }^{31} \mathrm{P}$ NMR spectrum, indicative of $C_{\mathrm{s}}$ symmetry.

\section{Conclusions}

The synthesis and structural studies above focus on the difficulties inherent in the generation of organometallic complexes that are legitimately "Fe(IV)" and, by virtue of true $\mathrm{Fe}=\mathrm{C}$ bonds, capable of olefin metathesis. Previously synthesized complexes, [mer- $\left\{\kappa-\mathrm{C}, \mathrm{N}, \mathrm{C}-\left(2-\mathrm{C}_{6} \mathrm{H}_{4}\right) \mathrm{CH}=\mathrm{N}(1,2-\right.$ 
$\left.\left.\left.\mathrm{C}_{6} \mathrm{H}_{4}\right) \mathrm{C}\left({ }^{\mathrm{i}} \mathrm{Pr}\right)=\right\} \mathrm{Fe}(\mathrm{PMe})_{3}\right]\left[\mathrm{B}\left(3,5-\left(\mathrm{CF}_{3}\right)_{2}-\mathrm{C}_{6} \mathrm{H}_{3}\right)_{4}\right]$ (1) and mer, trans-\{K-C,N,C- $\left(2-\mathrm{C}_{6} \mathrm{H}_{4}\right) \mathrm{CH}(\mathrm{Bn}) \mathrm{N}\left(1,2-\mathrm{C}_{6} \mathrm{H}_{4}\right) \mathrm{C}$ ('Pr) $=3 \mathrm{Fe}\left(\mathrm{PMe}_{3}\right)_{2} \mathrm{~N}_{2}(4-\mathrm{Bn})$, which can be depicted via a standard valence bond description as containing $\mathrm{Fe}(\mathrm{IV})=\mathrm{C}$ entities, have been investigated via calculations. They are shown to be more realistically interpreted as Fe(II), as the molecular orbitals portray the "alkylidenes" in $\mathbf{1}$ as a carbenium-like, i.e., Fe-C $\left(R, R^{\prime}\right)(+)$, and in 4-Ph as a vinyl, due to the importance of the 2e- oxidized form of the 1,2(RN), (C'Pr) $-\mathrm{C}_{6} \mathrm{H}_{4}$ constituent of the chelate (Fig. 2). [8]

Choosing to stay optimistic within the framework of the calculations, there still may be enough double bond character in the pseudo-Fe(IV) complexes to mediate olefin metathesis, provided "Fe=CHR" functionalities can be generated. The established route to iron alkylidenes is the protonation of iron vinyl complexes with $\mathrm{H}\left[\mathrm{BAr}_{4}^{\mathrm{F}}\right]$, but while suitable precursors were prepared, mer, trans- $\left\{\kappa^{3}\right.$ $\left.\mathrm{N}, \mathrm{N}, \mathrm{C}-2-\mathrm{py}-\mathrm{CH}=\mathrm{NCH}_{2} \mathrm{CH}=\mathrm{CH}\right\} \mathrm{Fe}\left(\mathrm{PMe}_{3}\right)_{2} \mathrm{CH}_{3}(6)$ and mer, trans- $\left\{\kappa^{3}-\mathrm{N}, \mathrm{N}, \mathrm{C}-2-\mathrm{py}-\mathrm{CH}=\mathrm{N} \mathrm{CH} \mathrm{CH}_{2} \mathrm{CH}=\mathrm{CH}\right\} \mathrm{Fe}\left(\mathrm{PMe}_{3}\right)_{2} \mathrm{I}$ (9), protonation appeared to cleave the $\mathrm{Fe}-\mathrm{CH}_{3}$ bond in 6 and the Fe-Vy bond in 9 . In an attempt to replace the iodide with tert-butoxide in $\mathbf{9}$, its dehydroiodination was effected, and a putative Fe(II)

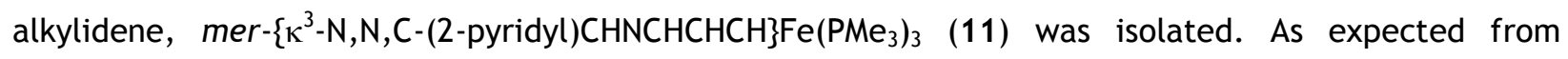
predictions, [6] its structure is best considered as an Fe(II) vinyl complex with a cationic iron center, and an anionic chelate in which the charge is highly delocalized in its $\pi$-system.

While it is easy to be discouraged by these and previous findings with regard to base metal catalysis of olefin metathesis, it is clear that stronger fields must be entrained in lower coordinate environments, and the pursuit of an "Fe=CHR" functionality must be realized, in order for the desired reactivity to have a chance at being observed.

\section{Experimental}

4.1. General Considerations.

All manipulations were performed using either glovebox or high vacuum line techniques, unless stated otherwise. All glassware was oven dried at $180{ }^{\circ} \mathrm{C}$. THF and ether were distilled under nitrogen from purple sodium benzophenone ketyl and vacuum transferred from the same prior to use. 
Hydrocarbon solvents were treated in the same manner with the addition of 1-2 $\mathrm{mL} / \mathrm{L}$ tetraglyme. Benzene- $d_{6}$ was dried over sodium, vacuum transferred and stored over sodium. THF $-d_{8}$ was dried over sodium, and vacuum transferred from sodium benzophenone ketyl prior to use. Chloroform- $d_{1}$ (Cambridge Isotope Laboratories) was used as received. 2- $\mathrm{Py}-\mathrm{CH}=\mathrm{NCH}_{2} \mathrm{CH}=\mathrm{CH}_{2}$, [32] E$\mathrm{PhCH}=\mathrm{CHCMe} 2 \mathrm{NH}_{2},[33-35] \quad$ cis-Me $(\mathrm{I}) \mathrm{Fe}\left(\mathrm{PMe}_{3}\right)_{4}, \quad$ cis-Me $\left.\mathrm{Me}_{2} \mathrm{FeMe}\right)_{4},[20] \quad\left[\left(\mathrm{Et}_{2} \mathrm{O}\right)_{2} \mathrm{H}\right]\left[\left(3,5-\left(\mathrm{CF}_{3}\right)_{2} \mathrm{C}_{6} \mathrm{H}_{3}\right)_{4} \mathrm{~B}\right]$ $\left(\mathrm{H}\left[\mathrm{BAr}_{4}^{\mathrm{F}}\right]\right),[24] \mathrm{Fe}\left(\mathrm{PMe}_{3}\right)_{4}$, and $\mathrm{FeCl}_{2}\left(\mathrm{PMe}_{3}\right)_{2}[29,30]$ were prepared according to literature procedures. NMR spectra were obtained using Inova $400 \mathrm{MHz}, 500 \mathrm{MHz}$ and $600 \mathrm{MHz}$ spectrometers. Chemical shifts are reported relative to benzene- $d_{6}\left({ }^{1} \mathrm{H} \delta 7.16 ;{ }^{13} \mathrm{C}\left\{{ }^{1} \mathrm{H}\right\} \delta 128.39\right)$, THF $-d_{8}\left({ }^{1} \mathrm{H} \delta 3.58\right.$; $\left.{ }^{13} \mathrm{C}\left\{{ }^{1} \mathrm{H}\right\} \delta 67.57\right)$ and chloroform $-d_{1}\left({ }^{1} \mathrm{H} \delta 7.26 ;{ }^{13} \mathrm{C}\left\{{ }^{1} \mathrm{H}\right\} \delta 77.16\right)$. Accurate mass data were acquired on an Exactive Orbitrap mass spectrometer (Thermo Scientific) using a DART (lonSense Inc., Saugus, MA) ion source in positive ion mode and He for ionization, while software affiliated with the spectrometer was used to calculate the molecular weight. Solution magnetic measurements were conducted via Evans' method in THF- $d_{8} .[27]$ Elemental analyses were performed by Robertson Microlit Laboratories, Madison, New Jersey.

\subsection{Procedures}

\subsection{1. $E-2-p y-\mathrm{CH}=\mathrm{NCMe}{ }_{2} \mathrm{CH}=\mathrm{CHPh}$.}

To a 25-mL flask containing 2-pyridinecarboxaldehyde $(0.23 \mathrm{~g}, 2.1 \mathrm{mmol})$ and $(\mathrm{E})$-2-methyl-4-phenyl-3buten-2-amine $(0.34 \mathrm{~g}, 2.1 \mathrm{mmol})$ was added $10 \mathrm{~mL} \mathrm{CH} \mathrm{Cl}_{2}$. Oven dried $4 \AA$ sieves $(2 \mathrm{~g})$ were added to the solution, and the flask was covered with a rubber stopper and stirred for $20 \mathrm{~h}$. The solution was filtered, and the volatiles removed, yielding the product as a yellow oil $(0.28 \mathrm{~g}, 53 \%) .{ }^{1} \mathrm{H} \mathrm{NMR}\left(\mathrm{CDCl}_{3}\right): \delta$ $1.52\left(6 \mathrm{H}, \mathrm{s}, \mathrm{CH}_{3}\right), 6.34(1 \mathrm{H}, \mathrm{d}, 16 \mathrm{~Hz}, \mathrm{Ph}-\mathrm{CH}=\mathrm{CH}), 6.53(1 \mathrm{H}, \mathrm{d}, 16 \mathrm{~Hz}, \mathrm{Ph}-\mathrm{CH}=\mathrm{CH}), 7.22(1 \mathrm{H}, \mathrm{t}, 7 \mathrm{~Hz}, p-$ Ph C-H), 7.29-7.33 (3H, m, m-Ph C-H and pyridyl-5-CH), $7.40(2 \mathrm{H}, \mathrm{d}, 8 \mathrm{~Hz}, o-\mathrm{Ph} \mathrm{C}-\mathrm{H}), 7.74(1 \mathrm{H}, \mathrm{t}, 8 \mathrm{~Hz}$, pyridyl-4-CH), $8.07\left(1 \mathrm{H}, \mathrm{d}, 8 \mathrm{~Hz}\right.$, pyridyl-3-CH), $8.43(1 \mathrm{H}, \mathrm{s}, \mathrm{N}=\mathrm{CH}), 8.63\left(1 \mathrm{H}, \mathrm{d}, 5 \mathrm{~Hz}\right.$, pyridyl-6-CH). ${ }^{13} \mathrm{C}$ NMR $\left(\mathrm{CDCl}_{3}\right): \delta 28.32,61.76,121.28,124.70,126.49,127.46,128.49,128.60,136.64,136.79,137.20$, 149.44, 155.35, 158.64. HRMS (DART-MS) m/z: [M + H] Calcd for 251.1504; Found 251.1536. 


\subsection{2. mer, trans- $\left\{\kappa^{3}-\mathrm{N}, \mathrm{N}, \mathrm{C}-2-\mathrm{py}-\mathrm{CH}=\mathrm{NCH}_{2} \mathrm{CH}=\mathrm{CH}\right\} \mathrm{Fe}\left(\mathrm{PMe}_{3}\right)_{2} \mathrm{CH}_{3}(6)$.}

A $60 \mathrm{~mL}$ bomb reactor was charged with 2-py- $\mathrm{CH}=\mathrm{NCH}_{2} \mathrm{CH}=\mathrm{CH}_{2}(300 \mathrm{mg}, 2.05 \mathrm{mmol})$ and $5 \mathrm{~mL}$ benzene. A separate vial was charged with cis- $\left(\mathrm{PMe}_{3}\right)_{4} \mathrm{Fe}\left(\mathrm{CH}_{3}\right)_{2}(801 \mathrm{mg}, 2.05 \mathrm{mmol})$ and $5 \mathrm{~mL}$ benzene, and the solution was added to the bomb, resulting in an immediate color change from faint yellow to dark violet. The mixture was warmed to $30{ }^{\circ} \mathrm{C}$ and stirred for $2 \mathrm{~d}$, with the solution gradually changing color to dark brown. The volatiles were removed in vacuo, and the solid residue was taken up in diethyl ether and transferred to a separate $50-\mathrm{mL}$ flask. The solvent was removed in vacuo, and the solid was washed with pentane $(3 \times 25 \mathrm{~mL})$ and filtered. The pentane solution was concentrated, cooled to $-78{ }^{\circ} \mathrm{C}$ for $30 \mathrm{~min}$, and filtered to afford brown crystals of $6(684 \mathrm{mg}, 90 \%) .{ }^{1} \mathrm{H}$ NMR $\left(\mathrm{C}_{6} \mathrm{D}_{6}\right): \delta 0.57(18 \mathrm{H}, \mathrm{t}, 3$ $\left.\mathrm{Hz}, \mathrm{P}\left(\mathrm{CH}_{3}\right)_{3}\right), 1.37(3 \mathrm{H}, \mathrm{t}, 13 \mathrm{~Hz}, \mathrm{Me}), 4.39\left(2 \mathrm{H}, \mathrm{br} \mathrm{s}, \mathrm{CH}_{2}\right), 6.45\left(1 \mathrm{H}, \mathrm{dtt}, 9,7,2 \mathrm{~Hz}, \mathrm{NCH}_{2} \mathrm{CH}\right), 6.90(1 \mathrm{H}$, br d, $8 \mathrm{~Hz}, \mathrm{py}-3-\mathrm{CH}), 7.01(1 \mathrm{H}, \mathrm{td}, 7,2 \mathrm{~Hz}, \mathrm{py}-4-\mathrm{CH}), 7.04(1 \mathrm{H}, \mathrm{ddt}, 9,6,2 \mathrm{~Hz}, \mathrm{Fe}-\mathrm{CH}=\mathrm{CH}), 7.08(1 \mathrm{H}$, m, $9 \mathrm{~Hz}, \mathrm{py}-5-\mathrm{CH}), 8.55(1 \mathrm{H}, \mathrm{d}, 6 \mathrm{~Hz}, \mathrm{py}-6-\mathrm{CH}), 9.05(1 \mathrm{H}, \mathrm{s}, \mathrm{N}=\mathrm{CH}) .{ }^{13} \mathrm{C} N M R\left(\mathrm{C}_{6} \mathrm{D}_{6}\right): \delta-6.17(\mathrm{t}, 34 \mathrm{~Hz})$, $10.14(t, 11 \mathrm{~Hz}), 69.63,120.60,121.07,125.77,126.18,152.34,152.65,161.76,174.29$ (t, $37 \mathrm{~Hz}) .{ }^{31} \mathrm{P}$ NMR $\left(C_{6} D_{6}\right): \delta$ 9.04. Anal. for $\mathrm{C}_{16} \mathrm{H}_{30} \mathrm{FeN}_{2} \mathrm{P}_{2}$ (calc.) C 52.19, H 8.21, N 7.61; (found) C 51.92, H 8.04, N 7.55 .
4.2.3. mer, trans- $\left\{\kappa^{3}-\mathrm{N}, \mathrm{N}, \mathrm{C}-2-\mathrm{py}-\mathrm{CH}=\mathrm{NCH}_{2} \mathrm{CH}=\mathrm{CH}\right\} \mathrm{Fe}\left(\mathrm{PMe}_{3}\right)_{2} \mathrm{CH}_{3}$
(6) via cis, trans-(2-py- $\mathrm{CH}=\mathrm{NCH}_{2}$ $\left.\mathrm{CH}=\mathrm{CH}_{2}\right) \mathrm{Cl}_{2}\left(\mathrm{PMe}_{3}\right)_{2}$ (7).

a. To a $25 \mathrm{~mL}$ flask charged with 2-py- $\mathrm{CH}=\mathrm{NCH}_{2} \mathrm{CH}=\mathrm{CH}_{2}(121 \mathrm{mg}, 0.828 \mathrm{mmol})$ and $\mathrm{FeCl}_{2}\left(\mathrm{PMe}_{3}\right)_{2}(231$ $\mathrm{mg}, 0.828 \mathrm{mmol}$ ) was added $5 \mathrm{~mL}$ THF via vacuum transfer at $-78{ }^{\circ} \mathrm{C}$. The solution was allowed to warm to $23{ }^{\circ} \mathrm{C}$, changed to a magenta color, and was stirred for an additional $3 \mathrm{~h}$. The volatiles were removed in vacuo, and the magenta solid was washed with pentane $(3 \times 10 \mathrm{~mL})$. The pentane solution was filtered, affording magenta crystals of $7(204 \mathrm{mg}, 58 \%) .{ }^{1} \mathrm{H}$ NMR $\left(T H F-d_{8}\right): \delta 1.18\left(v_{1 / 2}=14 \mathrm{~Hz}\right)$, $62.94\left(v_{1 / 2}=588 \mathrm{~Hz}\right)$; low solubility hampered analysis by NMR spectroscopy. Crystalline 7 was used without further purification or analysis. b. To a $25 \mathrm{~mL}$ flask fitted with a stopcock and charged with 7 
(75 mg, $0.18 \mathrm{mmol}$ ) was added $10 \mathrm{~mL}$ THF via vacuum transfer at $-78{ }^{\circ} \mathrm{C}$. The magenta solution was warmed to $23{ }^{\circ} \mathrm{C}$, and $\mathrm{MeLi}\left(1.6 \mathrm{M}\right.$ in $\left.\mathrm{Et}_{2} \mathrm{O}, 0.22 \mathrm{~mL}, 0.35 \mathrm{mmol}\right)$ was added via syringe. The solution was stirred for $20 \mathrm{~h}$, and became dark brown. The volatiles were removed and the residue was washed with pentane $(3 \times 10 \mathrm{~mL})$, yielding an oily brown material. ${ }^{1} \mathrm{H}$ and ${ }^{31} \mathrm{P}$ NMR spectra $\left(\mathrm{C}_{6} \mathrm{D}_{6}\right)$ were consistent with the production of $6 .{ }^{1} \mathrm{H}$ NMR $\left(\mathrm{THF}-d_{8}\right): \delta 62.94\left(v_{1 / 2}=534 \mathrm{~Hz}\right)$.

\subsection{4. [mer, trans- $\left.\left\{\kappa^{3}-\mathrm{N}, \mathrm{N}, \mathrm{C}-2-\mathrm{py}-\mathrm{CH}=\mathrm{NCH}_{2} \mathrm{CH}=\mathrm{CH}\right\} \mathrm{Fe}\left(\mathrm{PMe}_{3}\right)_{2} \mathrm{CH}_{3}\right][\mathrm{X}]\left(8, \mathrm{X}=\mathrm{PF}_{6}{ }^{-}\right)$.}

To a 25-mL flask charged with $6(100 \mathrm{mg}, 0.272 \mathrm{mmol})$ and $\left[\mathrm{Cp}_{2} \mathrm{Fe}_{\mathrm{PF}}(90 \mathrm{mg}, 0.27 \mathrm{mmol})\right.$ was added $10 \mathrm{~mL}$ THF via vacuum transfer at $-78{ }^{\circ} \mathrm{C}$. The dark brown solution was allowed to warm slowly over 20 $\mathrm{h}$, and a color change to violet was observed at $23{ }^{\circ} \mathrm{C}$. The volatiles were removed and the residue washed with pentane $(3 \times 10 \mathrm{~mL})$. Violet microcrystals $(113 \mathrm{mg}, 81 \%)$ were collected via filtration of the pentane solution after washing with pentane. ${ }^{1} \mathrm{H}$ NMR $\left(\right.$ THF $\left.-d_{8}\right): \delta-14.06\left(v_{1 / 2}=775 \mathrm{~Hz}\right), 6.39\left(v_{1 / 2}=\right.$ $105 \mathrm{~Hz}) . \mu_{\text {eff }}($ Evans $)=1.9 \mu_{\mathrm{B}}$.

\subsection{5. mer, trans- $\left\{\kappa^{3}-\mathrm{N}, \mathrm{N}, \mathrm{C}-(2-\mathrm{pyridyl}) \mathrm{CHNCH}_{2} \mathrm{CHCH}\right\} \mathrm{Fe}\left(\mathrm{PMe}_{3}\right)_{2} \mathrm{I}$ (9).}

To a $25-\mathrm{mL}$ flask charged with $6(300 \mathrm{mg}, 0.815 \mathrm{mmol})$ and iodine $(103 \mathrm{mg}, 0.406 \mathrm{mmol})$ was added 12 $\mathrm{mL}$ THF at $-78{ }^{\circ} \mathrm{C}$. The solution was stirred under $\mathrm{N}_{2}$ for $3 \mathrm{~d}$ at $23{ }^{\circ} \mathrm{C}$, and the color gradually changed from dark brown to dark green. The volatiles were removed and the residue was washed with pentane (3x10 mL). The solid was taken up in $10 \mathrm{~mL} \mathrm{C}_{6} \mathrm{H}_{6}$ and filtered, followed by removal of the solvent and 3 $\mathrm{mL}$ of pentane was added to the residue. Brown microcrystals (106 mg, 26\%) were isolated via filtration. Crystals suitable for X-ray diffraction were obtained via slow evaporation of a concentrated $\mathrm{Et}_{2} \mathrm{O}$ solution. ${ }^{1} \mathrm{H}$ NMR $\left(\mathrm{C}_{6} \mathrm{D}_{6}\right): \delta 0.95\left(18 \mathrm{H}, \mathrm{tt}\right.$ ", $\left.4 \mathrm{~Hz}, \mathrm{PMe}_{3}\right), 3.89\left(2 \mathrm{H}\right.$, br s, $\left.\mathrm{CH}_{2}\right), 6.06(1 \mathrm{H}, \mathrm{q}, 7 \mathrm{~Hz}, \mathrm{~N}-$ $\left.\mathrm{CH}_{2}-\mathrm{CH}\right), 6.87(2 \mathrm{H}, \mathrm{t}, 8 \mathrm{~Hz}$, py-4/5-CH and $\mathrm{Fe}-\mathrm{CH}=\mathrm{CH}), 6.93(1 \mathrm{H}, \mathrm{t}, 7 \mathrm{~Hz}, \mathrm{py}-5-\mathrm{CH}), 7.93(1 \mathrm{H}, \mathrm{dt}, 8,2$ $\mathrm{Hz}$, Fe- $\mathrm{CH}=\mathrm{CH}), 8.40(1 \mathrm{H}, \mathrm{s}, \mathrm{N}=\mathrm{CH}), 9.68(1 \mathrm{H}, \mathrm{d}, 6 \mathrm{~Hz}, \mathrm{py}-6-\mathrm{CH}) .{ }^{13} \mathrm{C}\left\{{ }^{1} \mathrm{H}\right\} \mathrm{NMR}\left(\mathrm{C}_{6} \mathrm{D}_{6}\right): \delta 12.69(\mathrm{t}, 12 \mathrm{~Hz})$, 67.71 (t, $3 \mathrm{~Hz}), 121.68,121.99,125.02$ (t, $6 \mathrm{~Hz}), 129.45,157.44,157.77$ (t, $2 \mathrm{~Hz}), 160.06,172.47$ (t, 33 
$\mathrm{Hz}$ ). ${ }^{31} \mathrm{P}$ NMR $\left(\mathrm{C}_{6} \mathrm{D}_{6}\right): \delta$-1.16. Anal. for $\mathrm{C}_{15} \mathrm{H}_{27} \mathrm{FeN}_{2} \mathrm{P}_{2} \mathrm{I}$ (calc.) C 37.53, H 5.67, N 5.84; (found) C 37.80, $\mathrm{H}$ 5.62, N 5.75 .

4.2.6. $\operatorname{mer}-\left\{\kappa^{3}-\mathrm{N}, \mathrm{N}, \mathrm{C}-(2-\mathrm{pyridyl}) \mathrm{CHNCHCHCH}\right\} \mathrm{Fe}\left(\mathrm{PMe}_{3}\right)_{3}(11)$.

A $25-\mathrm{ml}$ flask fitted to a $31-\mathrm{mL}$ gas bulb was charged with 9 (40 mg, $0.081 \mathrm{mmol})$ and ${ }^{\mathrm{t}} \mathrm{BuOK}(9 \mathrm{mg}, 0.80$ mmol). $\mathrm{PMe}_{3}(4.9 \mathrm{~cm} \mathrm{Hg}, 0.081 \mathrm{mmol})$ was transferred via vacuum transfer to the gas bulb, and subsequently frozen in the flask at $77 \mathrm{~K} .5 \mathrm{~mL}$ THF was vacuum transferred to the flask, and the solution warmed to $-78{ }^{\circ} \mathrm{C}$. The dark green solution was allowed to warm slowly to $23{ }^{\circ} \mathrm{C}$ over $15 \mathrm{~h}$, and the color changed to orange-brown. The volatiles were removed and the residue was washed with pentane $(3 \times 5 \mathrm{~mL})$. The residue was taken up in pentane and filtered, followed by removal of the solvent to afford a dark brown solid (39 mg, >95\%). Crystals suitable for X-ray diffraction were obtained via slow evaporation of a concentrated pentane solution at $-30{ }^{\circ} \mathrm{C} .{ }^{1} \mathrm{H} N M R\left(\mathrm{C}_{6} \mathrm{D}_{6}\right): \delta 1.03(9 \mathrm{H}, \mathrm{d}, 5 \mathrm{~Hz}$, $\left.\mathrm{PMe}_{3}\right), 1.30\left(18 \mathrm{H}\right.$, "t", $\left.\mathrm{PMe}_{3}\right), 5.24(1 \mathrm{H}, \mathrm{m}, 6,2 \mathrm{~Hz}, \mathrm{py}-4-\mathrm{CH}), 5.63(1 \mathrm{H}, \mathrm{br} \mathrm{dt}, 9,1 \mathrm{~Hz}, \mathrm{py}-3-\mathrm{CH}), 5.66$ $(1 \mathrm{H}, \mathrm{q}, 2 \mathrm{~Hz}, \mathrm{~N}-\mathrm{CH}-\mathrm{py}), 6.33(1 \mathrm{H}, \mathrm{m}, 7,1 \mathrm{~Hz}, \mathrm{py}-5-\mathrm{CH}), 6.52(1 \mathrm{H}, \mathrm{tq}, 4,2 \mathrm{~Hz}, \mathrm{FeCH}=\mathrm{CH}-\mathrm{CH}), 6.56(1 \mathrm{H}$, $\mathrm{dtt}, 8,4,1 \mathrm{~Hz}, \mathrm{Fe}-\mathrm{CH}=\mathrm{CH}), 6.70(1 \mathrm{H}, \mathrm{d}, 6 \mathrm{~Hz}, \mathrm{py}-6-\mathrm{Hz}), 6.93(1 \mathrm{H}, \mathrm{dtt}, 7,3,2 \mathrm{~Hz}, \mathrm{Fe}-\mathrm{CH}) .{ }^{13} \mathrm{C}\left\{{ }^{1} \mathrm{H}\right\} \mathrm{NMR}$ $\left(\mathrm{C}_{6} \mathrm{D}_{6}\right): \delta 15.95$ (dd, 10 and $\left.2 \mathrm{~Hz}\right), 16.05$ (dd, 10 and $\left.2 \mathrm{~Hz}\right), 21.37$ (dt, 17 and $\left.3 \mathrm{~Hz}\right), 102.88(\mathrm{t}, 2 \mathrm{~Hz})$, 103.85, 108.28 (t, $2 \mathrm{~Hz}), 133.03$ (t, $2 \mathrm{~Hz}), 136.81$ (d, $8 \mathrm{~Hz}), 138.84$ (t, $2 \mathrm{~Hz}), 153.93$ (d, $3 \mathrm{~Hz}), 161.81$ (d, $3 \mathrm{~Hz}), 189.39$ (td, 25 and $12 \mathrm{~Hz}) .{ }^{31} \mathrm{P}$ NMR $\left(\mathrm{C}_{6} \mathrm{D}_{6}\right): \delta 19.36(\mathrm{ABB}$, "d", JPP $=54 \mathrm{~Hz}), 23.47\left(A B B^{\prime}\right.$, "t", $J_{\mathrm{PP}}$ $=51 \mathrm{~Hz}$ ). Anal. for $\mathrm{C}_{18} \mathrm{H}_{36} \mathrm{FeN}_{2} \mathrm{P}_{3}$ (calc.) C 50.48, H 8.24, N 6.54; (found) C 50.29, H 7.92, N 6.45.

\subsection{7. $\operatorname{mer}-\left\{\kappa^{3}-\mathrm{C}, \mathrm{N}, \mathrm{C}-\left(2-\mathrm{C}_{6} \mathrm{H}_{4}\right) \mathrm{CH}=\mathrm{NCH}_{2} \mathrm{CH}=\mathrm{CH}\right\} \mathrm{Fe}\left(\mathrm{PMe}_{3}\right)_{3}$ (12).}

To a $50 \mathrm{~mL}$ flask charged with $\mathrm{PhCH}=\mathrm{NCH}_{2} \mathrm{CH}=\mathrm{CH}_{2}(176 \mathrm{mg}, 1.21 \mathrm{mmol})$ and cis- $\mathrm{Me}_{2} \mathrm{Fe}\left(\mathrm{PMe}_{3}\right)_{4}(473 \mathrm{mg}$, $1.21 \mathrm{mmol}$ ) was added $15 \mathrm{~mL}$ THF via vacuum transfer at $-78{ }^{\circ} \mathrm{C}$. The red solution was allowed to slowly warm to $23{ }^{\circ} \mathrm{C}$ for $1 \mathrm{~d}$, resulting in a color change to orange-brown. The volatiles were removed in vacuo, and the residue washed with pentane $(3 \times 15 \mathrm{~mL})$. The pentane solution was filtered, concentrated and cooled to $-78{ }^{\circ} \mathrm{C}$ for $30 \mathrm{~min}$. The solution was filtered, affording the product as a 
brown solid (447 mg, 87\%). ${ }^{1} \mathrm{H}$ NMR $\left(\mathrm{C}_{6} \mathrm{D}_{6}\right): \delta 0.74(18 \mathrm{H}, \mathrm{t}, 3 \mathrm{~Hz}), 1.25(9 \mathrm{H}, \mathrm{d}, 6 \mathrm{~Hz}), 4.37(2 \mathrm{H}, \mathrm{s}), 6.42$ $(1 \mathrm{H}, \mathrm{dt}, 5$ and $9 \mathrm{~Hz}), 7.06(1 \mathrm{H}, \mathrm{t}, 7 \mathrm{~Hz}), 7.14-7.18(1 \mathrm{H}, \mathrm{m}), 7.47(1 \mathrm{H}, \mathrm{d}, 7 \mathrm{~Hz}), 7.89-7.93(2 \mathrm{H}, \mathrm{m}), 8.00$ $(1 \mathrm{H}, \mathrm{m}) .{ }^{31} \mathrm{P} N M R\left(\mathrm{C}_{6} \mathrm{D}_{6}\right): \delta 22.02\left(\mathrm{ABB} B^{\prime}, \mathrm{d} ", J_{\mathrm{PP}}=64 \mathrm{~Hz}\right), 28.93\left(A B B^{\prime}\right.$, "t", $\left.J_{\mathrm{PP}}=63 \mathrm{~Hz}\right)$.

4.2.8. mer, trans- $\left\{\kappa^{3}-\mathrm{N}, \mathrm{N}, \mathrm{C}-(2-\mathrm{py}) \mathrm{CH}=\mathrm{NC}(\mathrm{Me})_{2} \mathrm{CH}=\mathrm{CH}\right\} \mathrm{Fe}\left(\mathrm{PMe}_{3}\right)_{2} \mathrm{CH}_{3}(13)$,

To a $50 \mathrm{~mL}$ flask charged with $E-2-p y-C H=N C M e_{2} C H=C H P h(0.25 \mathrm{~g}, 1.00 \mathrm{mmol})$ was added $5 \mathrm{~mL} \mathrm{C}_{6} \mathrm{H}_{6}$ at $23{ }^{\circ} \mathrm{C}$. To a separate vial charged with cis $-\mathrm{Me}_{2} \mathrm{Fe}\left(\mathrm{PMe}_{3}\right)_{4}(390 \mathrm{mg}, 0.999 \mathrm{mmol})$ was added $5 \mathrm{~mL} \mathrm{C}_{6} \mathrm{H}_{6}$, and this solution was added to the original, which became dark violet. The mixture was stirred at $23{ }^{\circ} \mathrm{C}$ for $2 \mathrm{~h}$. The volatiles were removed and the residue taken up in $10 \mathrm{~mL}$ pentane. The pentane mixture was filtered, concentrated and cooled to $-78{ }^{\circ} \mathrm{C}$ for 30 minutes, affording violet microcrystals that were collected by filtration (309 mg, 65\%). ${ }^{1} \mathrm{H}$ NMR $\left(\mathrm{C}_{6} \mathrm{D}_{6}\right): \delta 0.41\left(18 \mathrm{H}, \mathrm{t}, 3 \mathrm{~Hz}, \mathrm{PMe}_{3}\right), 1.97(6 \mathrm{H}, \mathrm{s}, \mathrm{N}-$ $\left.\mathrm{C}\left(\mathrm{CH}_{3}\right)_{2}\right), 2.13\left(3 \mathrm{H}, \mathrm{t}, 13 \mathrm{~Hz}, \mathrm{Fe}-\mathrm{CH}_{3}\right), 6.03(1 \mathrm{H}, \mathrm{t}, 6 \mathrm{~Hz}, \mathrm{Fe}-\mathrm{C}=\mathrm{CH}), 6.93(1 \mathrm{H}, \mathrm{m}, \mathrm{py}-3-\mathrm{CH}), 7.04(2 \mathrm{H}, \mathrm{m}$, py-4/5-CH), $7.14(1 \mathrm{H}, \mathrm{t}, 7 \mathrm{~Hz}, p-\mathrm{Ph} \mathrm{CH}), 7.19(2 \mathrm{H}, \mathrm{d}, 8 \mathrm{~Hz}, o-\mathrm{Ph} \mathrm{CH}), 7.31(1 \mathrm{H}, \mathrm{t}, 8 \mathrm{~Hz}, m-\mathrm{Ph} \mathrm{CH}), 8.41$ $\left(1 \mathrm{H}\right.$, br s, py-6-CH), $9.53(1 \mathrm{H}, \mathrm{s}, \mathrm{N}=\mathrm{CH}) .{ }^{13} \mathrm{C} N M R\left(\mathrm{C}_{6} \mathrm{D}_{6}\right): \delta-2.36(\mathrm{t}, 35 \mathrm{~Hz}), 12.63(\mathrm{t}, 9 \mathrm{~Hz}), 29.78,75.97$ (t, $2 \mathrm{~Hz}$ ), 120.50 (t, $2 \mathrm{~Hz}), 121.77,123.54,126.82,127.28,128.34,128.57,137.02$ (t, $4 \mathrm{~Hz}), 152.14$, 152.58, 154.86, 164.29, 170.71 (t, $32 \mathrm{~Hz}) .{ }^{31} \mathrm{P} \mathrm{NMR}\left(\mathrm{C}_{6} \mathrm{D}_{6}\right): \delta$ 0.56. Anal. for $\mathrm{C}_{24} \mathrm{H}_{38} \mathrm{FeN}_{2} \mathrm{P}_{2}$ (calc.) C 61.02, H 8.11, N 5.93; (found) C 60.73, H 8.01, N 5.99.

\subsection{9. [mer, trans- $\left.\left\{\kappa^{3}-\mathrm{N}, \mathrm{N}, \mathrm{C}-(2-\mathrm{py}) \mathrm{CH}=\mathrm{NC}(\mathrm{Me})_{2} \mathrm{CH}=\mathrm{CH}\right\} \mathrm{Fe}\left(\mathrm{PMe}_{3}\right)_{2} \mathrm{~N}_{2}\right]\left[\mathrm{BAr}{ }_{4}\right]$ (15).}

To a $50-\mathrm{mL}$ flask charged with $13(75 \mathrm{mg}, 0.16 \mathrm{mmol})$ and $\mathrm{H}\left[\mathrm{BAr}_{4}{ }_{4}\right](161 \mathrm{mg}, 0.159 \mathrm{mmol})$ was transferred $10 \mathrm{~mL}$ THF at $-78{ }^{\circ} \mathrm{C}$. The resulting blue solution was allowed to slowly warm to $23{ }^{\circ} \mathrm{C}$ over $45 \mathrm{~h}$. The volatiles were removed, and the violet solid was washed with pentane $(3 \times 10 \mathrm{~mL})$. The pentane solution was filtered, and violet microcrystals, which crystallized with 3 equiv THF, were collected $(170 \mathrm{mg}, 70 \%)$. Dissolution of the crystals in THF- $d_{8}$ under $\mathrm{N}_{2}$ produced a color change from blue to red-brown as 15 formed completely. ${ }^{1} \mathrm{H}$ NMR $\left(\mathrm{THF}-d_{8}\right): \delta 0.97\left(18 \mathrm{H}, \mathrm{t}, 4 \mathrm{~Hz}, \mathrm{PMe}_{3}\right), 1.62(6 \mathrm{H}, \mathrm{s}$, $\left.\mathrm{N}-\mathrm{C}\left(\mathrm{CH}_{3}\right)_{2}\right), 1.77(12 \mathrm{H}, \mathrm{m}, \mathrm{THF}), 3.62(12 \mathrm{H}, \mathrm{m}, \mathrm{THF}), 5.71(1 \mathrm{H}, \mathrm{t}, 6 \mathrm{~Hz}, \mathrm{Fe}-\mathrm{C}=\mathrm{CH}), 7.05(1 \mathrm{H}, \mathrm{br}$, py-3- 
$\mathrm{CH}), 7.15(1 \mathrm{H}, \mathrm{t}, 7 \mathrm{~Hz}, p-\mathrm{Ph} \mathrm{CH}), 7.20(2 \mathrm{H}, \mathrm{d}, 8 \mathrm{~Hz}, o-\mathrm{Ph} \mathrm{CH}), 7.28(2 \mathrm{H}, \mathrm{t}, 7 \mathrm{~Hz}, m-\mathrm{Ph} \mathrm{CH}), 7.55(4 \mathrm{H}, \mathrm{br}$ s, $\left.\mathrm{BAr}_{4}{ }_{4} \mathrm{p}-\mathrm{Ph} \mathrm{CH}\right), 7.76\left(9 \mathrm{H}, \mathrm{br} \mathrm{s}, \mathrm{BAr}_{4}^{\mathrm{F}} \mathrm{O}-\mathrm{Ph} \mathrm{CH}\right), 8.11(2 \mathrm{H}, \mathrm{d}, 4 \mathrm{~Hz}, \mathrm{py}-(4,5)-\mathrm{CH}), 8.94(1 \mathrm{H}, \mathrm{d}, 6 \mathrm{~Hz}, \mathrm{py}-$ 6-CH), $9.06(1 \mathrm{H}, \mathrm{t}, 5 \mathrm{~Hz}, \mathrm{~N}=\mathrm{CH}) .{ }^{13} \mathrm{C}$ NMR $\left(\mathrm{THF}-d_{8}\right): \delta 11.63$ (t, $\left.12 \mathrm{~Hz}\right), 29.74,75.35$ (t, $\left.2 \mathrm{~Hz}\right), 118.29$, 122.36, 124.53, 126.29, 126.70, 128.08, 128.63, 128.65, 128.86, 129.98 (q, $32 \mathrm{~Hz}), 135.70,136.75$ (t, 5 $\mathrm{Hz}), 137.60,152.08,160.60,162.32(\mathrm{~d}, 50 \mathrm{~Hz}), 163.11$ (d, $50 \mathrm{~Hz}), 170.41(24 \mathrm{~Hz}) .{ }^{31} \mathrm{P}$ NMR $\left(\mathrm{THF}-d_{8}\right): \delta$ 9.10. IR (nujol): $v\left(\mathrm{~N}_{2}\right)=2116 \mathrm{~cm}^{-1}$.

4.3. Attempt to Synthesize 9 on NMR Tube Scale from $\left(\mathrm{Me}_{3} \mathrm{P}\right)_{4} \mathrm{Fel}\left(\mathrm{CH}_{3}\right)$ : Evidence for trans- $\left\{\kappa^{2}-\mathrm{N}, \mathrm{N}\right.$ 2-py- $\left.\mathrm{CH}=\mathrm{NCH}_{2} \mathrm{CH}=\mathrm{CH}_{2}\right\} \mathrm{Fe}\left(\mathrm{PMe}_{3}\right)_{2}\left(\mathrm{CH}_{3}\right) \mathrm{l}(10)$.

To an NMR tube charged with 2-py- $\mathrm{CH}=\mathrm{NCH}_{2} \mathrm{CH}=\mathrm{CH}_{2}(7 \mathrm{mg}, 0.05 \mathrm{mmol})$ and $\mathrm{MeFe}(\mathrm{I})\left(\mathrm{PMe}_{3}\right)_{4}(24 \mathrm{mg}$, $0.048 \mathrm{mmol}$ ) was added $573 \mathrm{mg} \mathrm{C}_{6} \mathrm{D}_{6}$, resulting in a dark green solution. The tube was flame sealed with a torch, and NMR spectra were taken over the course of $80 \mathrm{~h}$ at $23,30,55,75,90$, and $130{ }^{\circ} \mathrm{C}$. No color change from the initial green was observed despite temperature and reaction time. The major product was characterized by ${ }^{1} \mathrm{H}$ and ${ }^{31} \mathrm{P}$ NMR. ${ }^{1} \mathrm{H}$ NMR $\left(\mathrm{C}_{6} \mathrm{D}_{6}\right): \delta 0.95(18 \mathrm{H}$, br s, PMe $), 1.32(3 \mathrm{H}, \mathrm{br} \mathrm{t}, 3$ $\left.\mathrm{Hz}, \mathrm{PMe}_{3}\right), 3.87\left(2 \mathrm{H}, \mathrm{s}, \mathrm{N}-\mathrm{CH}_{2}\right), 5.86\left(1 \mathrm{H}, \mathrm{m}, \mathrm{N}-\mathrm{CH}_{2}-\mathrm{CH}=\mathrm{CH}_{2}\right), 6.06\left(1 \mathrm{H}, \mathrm{br} \mathrm{d}, 6 \mathrm{~Hz}, \mathrm{~N}-\mathrm{CH}_{2}-\mathrm{CH}=\mathrm{CH}_{2}\right), 6.82$ $\left(1 \mathrm{H}, \mathrm{m}, \mathrm{N}-\mathrm{CH}_{2}-\mathrm{CH}\right), 6.87(2 \mathrm{H}, \mathrm{m}, \mathrm{py}-(3,4)-\mathrm{CH}), 7.93(1 \mathrm{H}, \mathrm{m}, \mathrm{Fe}-\mathrm{CH}=\mathrm{CH}), 8.35(1 \mathrm{H}, \mathrm{s}, \mathrm{N}=\mathrm{CH}), 9.68(1 \mathrm{H}$, $\mathrm{s}$, py-6-CH). ${ }^{31} \mathrm{P}$ NMR $\left(\mathrm{C}_{6} \mathrm{D}_{6}\right): \delta-1.13$. 9 was produced in $54 \%$ conversion as determined by ${ }^{1} \mathrm{H}$ NMR, based on product-to-free ligand methylene ratios $(1.86: 1.59)$.

\subsection{X-ray Crystal Structure Determinations.}

\subsection{1. mer, trans- $\left\{\kappa^{3}-\mathrm{N}, \mathrm{N}, \mathrm{C}-(2-\mathrm{pyridyl}) \mathrm{CHNCH}_{2} \mathrm{CHCH}\right\} \mathrm{Fe}\left(\mathrm{PMe}_{3}\right)_{2} \mathrm{l}$ (9).}

A brown block measuring $0.280 \times 0.250 \times 0.220 \mathrm{~mm}^{3}$ was obtained from diethyl ether. Crystal data for $\mathrm{C}_{15} \mathrm{H}_{27} \mathrm{~N}_{2} \mathrm{P}_{2} \mathrm{IFe}, M=480.07 \mathrm{u}$, monoclinic, $\mathrm{P} 2_{1} / \mathrm{n}, a=8.5494(14), b=13.792(2), c=17.322(2) \AA$, $\beta=98.124(7)^{\circ}, V=2022.0(6) \AA^{3}, T=223(2), \lambda=0.71073 \AA, Z=4, \rho_{\text {calc }}=1.577 \mathrm{Mg} / \mathrm{m}^{3}, \mu=2.427 \mathrm{~mm}^{-1}$, 60292 reflections, 7352 independent $\left(R_{\text {int }}=0.0259\right), 5944$ independent $(I>2 \sigma(I)), R_{1}($ all data $)=0.0426$, 
$\mathrm{W} R_{2}=0.0830, R_{1}(l>2 \sigma(I))=0.0328, \mathrm{~W} R_{2}=0.0782, \mathrm{GOF}=1.078 . \mathrm{CCDC}-1448434$.

4.4.2. $\operatorname{mer}-\left\{\kappa^{3}-\mathrm{N}, \mathrm{N}, \mathrm{C}-(2-\right.$ pyridyl) $\mathrm{CHNCHCHCH}\} \mathrm{Fe}\left(\mathrm{PMe}_{3}\right)_{3}$ (11).

A red plate measuring $0.220 \times 0.180 \times 0.090 \mathrm{~mm}^{3}$ was obtained from pentane. Crystal data for $\mathrm{C}_{18} \mathrm{H}_{35} \mathrm{~N}_{2} \mathrm{P}$ Fe, $M=428.24 \mathrm{u}$, triclinic, P1bar, $a=8.8875(7), b=9.4239(7), c=14.2393(10) \AA, \alpha \square=$ $85.191(4)^{\circ}, \beta=81.684(4)^{\circ}, \gamma=70.182(4)^{\circ}, V=1109.41(15) \AA^{3}, T=223(2), \lambda=0.71073 \AA, Z=2, \rho_{\text {calc }}=$ $1.282 \mathrm{Mg} / \mathrm{m}^{3}, \mu=0.899 \mathrm{~mm}^{-1}, 27986$ reflections, 6774 independent $\left(R_{\text {int }}=0.0370\right), 5209$ independent $(I>2 \sigma(I)), R_{1}$ (all data) $=0.0557, \mathrm{w} R_{2}=0.1095, R_{1}(l>2 \sigma(I))=0.0410, \mathrm{w} R_{2}=0.1026, \mathrm{GOF}=1.060$. CCDC1448433.

\section{Supporting Information}

\subsection{Crystallography.}

CCDC-1448433 and CCDC-1448434 contains the supplementary crystallographic data for mer$\left\{k^{3}-\mathrm{N}, \mathrm{N}, \mathrm{C}-(2-\mathrm{pyridyl}) \mathrm{CHNCHCHCH}\right\} \mathrm{Fe}\left(\mathrm{PMe}_{3}\right)_{3} \quad(11)$ and mer, trans- $\left\{\kappa^{3}-\mathrm{N}, \mathrm{N}, \mathrm{C}-(2-\right.$ pyridyl $\left.) \mathrm{CHNCH}_{2} \mathrm{CHCH}\right\}$ $\mathrm{Fe}\left(\mathrm{PMe}_{3}\right)_{2} \mathrm{I}$ (9), respectively. These data can be obtained free of charge via http://www.ccdc.cam.ac.uk/cont/retrieving.html, or from the Cambridge Crystallographic Data Centre, 12 Union Road, Cambridge CB2 1EZ, UK; fax: (+44) 1223-336-033; or e-mail: deposit@ccdc.cam.ac.uk.

\subsection{Spectra and Calculations.}

Energies and views of critical orbitals in the electronic structure calculations of 1, 4-Bn, and 11 are listed and critical NMR spectra of the complexes are given.

\section{Acknowledgements}


Support from the National Science Foundation (PTW, CHE-1402149) is gratefully acknowledged, as is the U.S. Dept of Energy, Office of Basic Energy Sciences for partial support of this research (TRC, DE-FG02-03ER15387). Ala'aeddeen Swidan is acknowledged for the initial synthesis of compound 12.

\section{References}

[1] Y. Chauvin, Angew. Chem. Int. Ed. 45 (2006) 3740-3747.

[2] R. H. Grubbs, Angew. Chem. Int. Ed. 45 (2006), 3760-3765.

[3] R. R. Schrock, Angew. Chem. Int. Ed. 45 (2006) 3748-3759.

[4] V. M. Marx, A. H. Sullivan, M. Melaimi, S. C. Virgil, B. K. Keitz, D. S. Weinberger, G. Bertrand, R. H. Grubbs, Angew. Chem. Int. Ed. 54 (2015) 1919-1923.

[5] (a) R. R. Schrock, A. H. Hoveyda, Angew. Chem. Int. Ed. 42 (2003) 4592-4633. (b) H. Jeong, J. M. John, R. R. Schrock, A. H. Hoveyda, J. Am. Chem. Soc. 137 (2015) 2239-2242.

[6] O. Eisenstein, R. Hoffmann, A. R. Rossi, J. Am. Chem. Soc. 103 (1981) 5582-5584.

[7] B. M. Lindley, A. Swidan, E. B. Lobkovsky, P. T. Wolczanski, M. Adelhardt, J. Sutter, K. Meyer, Chem. Sci. 6 (2015) 4730-4736.

[8] B. M. Lindley, B. P. Jacobs, S. N. MacMillan, P. T. Wolczanski, Chem. Commun. 52 (2016) 38913894.

[9] (a) K. A. M. Kremer, G.-H. Kuo, E. J. O'Connor, P. Helquist, R. C. Kerber, J. Am. Chem. Soc. 104 (1982) 6119-6121. (b) G.-H. Kuo, P. Helquist, R. C. Kerber, Organometallics 3 (1984) 806808.

[10] T. Bodnar, A. R. Cutler, J. Organomet. Chem. 213 (1981) C31-C36.

[11] (a) A. Davison, J. P. Selegue, J. Am. Chem. Soc. 100 (1978) 7763-7765. (b) R. D. Adams, A. Davison, J. P. Selegue, J. Am. Chem. Soc. 101 (1979) 7232-7238.

[12] M. I. Bruce, A. G. Swincer, Aust. J. Chem. 33 (1980) 1471-1483. 
[13] C. P. Casey, W. H. Miles, H. Tukada, J. M. O'Connor, J. Am. Chem. Soc. 104 (1982) 3761-3762.

[14] R. J. Goddard, R. Hoffmann, E. D. Jemmis, J. Am. Chem. Soc. 102 (1980) 7667-7676.

[15] B. A. Frazier, E. R. Bartholomew, P. T. Wolczanski, S. DeBeer, M. Santiago-Berrios, H. D. Abruña, E. B. Lobkovsky, S. C. Bart, S. Mossin, K. Meyer, T. R. Cundari, Inorg. Chem. 50 (2011) 12414-12436.

[16] E. C. Volpe, P. T. Wolczanski, E. B. Lobkovsky, Organometallics 29 (2010) 364-377.

[17] (a) V. A. Williams, E. B. Hulley, P. T. Wolczanski, K. M. Lancaster, E. B. Lobkovsky, Chem. Sci. 4 (2013) 3636-3648. (b) E. B. Hulley, V. A. Williams, W. D. Morris, P. T. Wolczanski, K. HernándezBurgos, E. B. Lobkovsky, T. R. Cundari, Polyhedron 84 (2014) 182-191.

[18] (a) V. A. Williams, P. T. Wolczanski, J. Sutter, K. Meyer, E. B. Lobkovsky, T. R. Cundari, Inorg. Chem. 53 (2014) 4459-4474. (b) W. D. Morris, P. T. Wolczanski, J. Sutter, K. Meyer, T. R. Cundari, E. B. Lobkovsky, Inorg. Chem. 53 (2014) 7467-7484.

[19] (a) M. Brookhart, J. R. Tucker, G. R. Husk, J. Am. Chem. Soc. 105 (1983) 258-264. (b) M. Brookhart, J. R. Tucker, J. Am. Chem. Soc. 103 (1981) 979-981. (c) M. Brookhart, D. Timmers, J. R. Tucker, G. D. Williams, G. R. Husk, H. Brunner, B. Hammer, J. Am. Chem. Soc. 105 (1983) $6721-6723$

[20] H. H. Karsch, Chem. Ber. 110 (1977) 2699-2711.

[21] (a) G. Xu, H. Sun, X. Li, Organometallics 28 (2009) 6090-6095. (b) X. Xu, J. Jia, H. Sun, Y. Liu, W. Xu, Y. Shi, D. Zhang, X. Li, Dalton Trans. 42 (2013) 3417-3428.

[22] (a) R. Beck, T. Zheng, H. Sun, X. Li, U. Flörke, H.-F. Klein, J. Organomet. Chem. 693 (2008) 3471-3478. (b) S. Camadanli, R. Beck, U. Flörke, H.-F. Klein, Organometallics 28 (2009) 23002310. (c) H.-F. Klein, S. Camadanli, R. Beck, D. Leukel, U. Flörke, Angew. Chem. Int. Ed. 44 (2005) 975-977. (d) H.-F. Klein, S. Camadanli, R. Beck, U. Flörke, Chem. Commun. (2005) 381382.

[23] E. R. Bartholomew, E. C. Volpe, P. T. Wolczanski, E. B. Lobkovsky, T. R. Cundari, J. Am. Chem. Soc. 135 (2013) 3511-3527.

[24] M. Brookhart, B. Grant, A. F. Volpe, Jr., Organometallics 11 (1992) 3920-3922.

[25] M. Gomberg, J. Am. Chem. Soc. 22 (1900) 757-771. 
[26] W. P. Neumann, W. Uzick, A. K. Zarkadis, J. Am. Chem. Soc. 108 (1986) 3762-3770.

[27] (a) D. F. Evans, J. Chem. Soc. (1959) 2003-2005. (b) E. M. Schubert, J. Chem. Educ. 69 (1992) 62.

[28] B. N. Figgis, M. A. Hitchman, Ligand Field Theory and Its Applications; Wiley-VCH, New York, 2000.

[29] H. H. Karsch, Chem. Ber. 110 (1977) 2222-2235.

[30] (a) H. H. Karsch, H.-F. Klein, H. Schmidbauer, Chem. Ber. 110 (1977) 2200-2212. (b) H. Guan, P. Bhattacharya, J. A. Krause, Organometallics 30 (2011) 4720-4729.

[31] F. H. Allen, O. Kennard, D. G. Watson, L. Brammer, A. G. Orpen, R. Taylot, J. Chem. Soc. Perkin Trans. II (1987) S1-S19.

[32] R. C. Larock, D. C. Rogness, N. A. Markina, J. P. Waldo, J. Org. Chem. 77 (2012) 2743-2755.

[33] E. J. Alexanian, V. A. Schmidt, Angew. Chem. Int. Ed. 49 ( 2010) 4491-4494.

[34] M. Rueping, C. Vila, U. Uria, Org. Lett. 14 (2012) 768-771.

[35] A. Mi, W. Lin, X. Ziang, Z. He, Y. Jin, L. Gong, Synthetic Commun. 32 (2002) 3279-3284. 


\section{Graphical Abstract}

Fe(IV) Alkylidenes Are Actually Fe(II), and a Related Octahedral Fe(II) "Alkylidene" Is a Conjugated Vinyl Complex ${ }^{\ddagger}$

Brian P. Jacobs, ${ }^{a}$ Rishi G. Agarwal, ${ }^{a}$ Peter T. Wolczanski ${ }^{*},{ }^{a}$ Thomas R. Cundari ${ }^{*},{ }^{b}$ and Samantha N. MacMillan $^{a}$

${ }^{a}$ Department of Chemistry \& Chemical Biology, Baker Laboratory, Cornell University, Ithaca, New York 14853 (USA); E-mail: ptw2@cornell.edu

${ }^{b}$ Department of Chemistry, Center for Advanced Scientific Computing and Modeling (CASCaM), University of North Texas, Box 305070, Denton, Texas 76203-5070

${ }^{\ddagger}$ Dedicated to Prof. Malcolm L. H. Green, candidate for the Mt. Rushmore of organometallic chemistry, on the occasion of his 80th birthday; we greatly appreciate his contributions and enthusiasm.

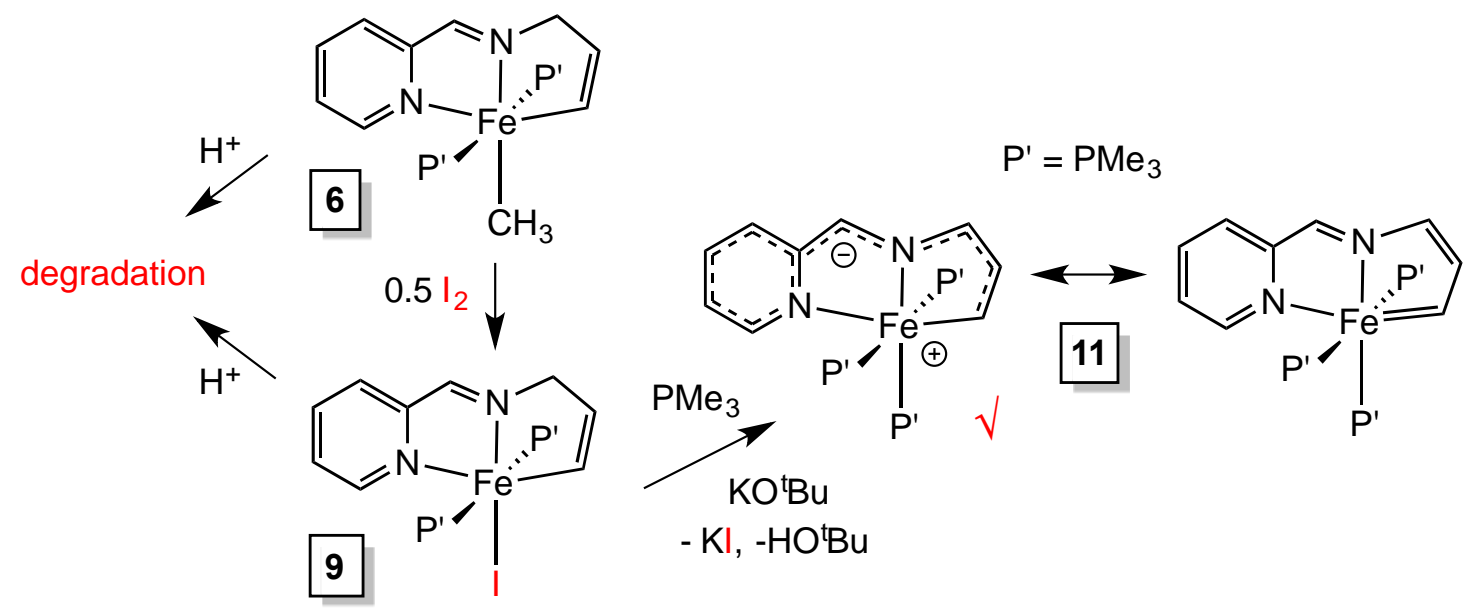




\section{Graphical Abstract}

Fe(IV) Alkylidenes Are Actually Fe(II), and a Related Octahedral Fe(II) "Alkylidene" Is a Conjugated Vinyl Complex ${ }^{\ddagger}$

Brian P. Jacobs, ${ }^{a}$ Rishi G. Agarwal, ${ }^{a}$ Peter T. Wolczanski*, ${ }^{a}$ Thomas R. Cundari*, ${ }^{b}$ and Samantha N. MacMillan $^{a}$

${ }^{a}$ Department of Chemistry \& Chemical Biology, Baker Laboratory, Cornell University, Ithaca, New York 14853 (USA); E-mail: ptw2@cornell.edu

${ }^{b}$ Department of Chemistry, Center for Advanced Scientific Computing and Modeling (CASCaM), University of North Texas, Box 305070, Denton, Texas 76203-5070

${ }^{\ddagger}$ Dedicated to Prof. Malcolm L. H. Green, candidate for the Mt. Rushmore of organometallic chemistry, on the occasion of his 80th birthday; we greatly appreciate his contributions and enthusiasm.

Calculations on previously synthesized "Fe(IV) alkylidenes" are more consistent with Fe(II) centers bound to carbenium and oxidized chelate ligands. Attempts to prepare $L_{n} F e=C H R$ species failed due unsuccessful protonation of precursor vinyl complexes, but the approach did yield an unusual "Fe(II) alkylidene" that was shown to be a delocalized vinyl complex. 